\title{
Theoretical Studies of the Structural, Mechanical and Raman Spectroscopic Properties of Uranyl-Containing Minerals
}

\author{
Francisco Colmenero Ruiz
}

Additional information is available at the end of the chapter

http://dx.doi.org/10.5772/

\begin{abstract}
The incipient use of theoretical methods in the research of geomaterials reveals the great power of such methodology in the determination of the mineral properties. These methods provide a safe, accurate and cheap manner of obtaining these properties. Uranium-containing minerals are highly radiotoxic, and their experimental studies demand a careful handling of the samples used. However, theoretical methods are free of such inconveniences and may be used in the complete characterization of this type of minerals. Theoretical methods are not only a complement to the use of other experimental techniques but also a powerful predictive tool. The structural, mechanical and Raman spectroscopic properties of uranyl-containing materials, including rutherfordine soddyite, schoepite and uranophane- $\alpha$, were studied by means of theoretical solid-state methods based on density functional theory using plane waves and pseudopotentials. A new norm-conserving relativistic pseudopotential for uranium atom developed in recent works was employed. These minerals are among the most important secondary phases arising from corrosion of spent nuclear fuel under the final geological disposal conditions. The computed crystal structures of these materials as well as the corresponding and X-ray powder patterns were found to be in excellent agreement with the experimental information. Therefore, the optimized structures of these minerals were employed to study the mechanical properties and stability of these minerals. These properties were obtained using the finite deformation technique. All these minerals were found to be mechanically stable since the corresponding Born stability conditions were satisfied. A large amount of relevant mechanical data were reported including bulk, Young and Shear moduli, Poisson ratios, ductility and hardness indices, anisotropy measures as well as longitudinal and transversal wave velocities. The large volume expansion and mechanical stress resulting from the corrosion of spent nuclear fuel during storage emphasize the great relevance of the mechanical information of the waste components. Finally, the computation of vibrational properties of these minerals is studied. The computed Raman spectra of these materials were found to be in good agreement with their experimental
\end{abstract}


counterparts when they were available for comparison. These results demonstrate the power of the theoretical methods in the research of uranium-containing minerals.

Keywords: uranyl-containing minerals, spent nuclear fuel, density functional theory, crystal structures, $X$-ray diffraction, mechanical properties, Raman spectroscopy, rutherfordine, soddyite, uranophane- $\alpha$, schoepite

\section{Introduction}

Nuclear energy covers a fundamental fraction of the increasing electricity requirements due to the growing populations and consumption. It provides a continuous and sustainable energy source independent of the climate and local conditions and free of $\mathrm{CO}_{2}$ emissions and other greenhouse gases causing global warming [1-3]. However, nuclear power installations produce high-level radioactive nuclear waste (HLRW) whose management is very complicated and can be a source of high ecological damage [1-4]. Special care must be dedicated to the avoidance of nuclear accidents [5]. The need of extreme care to avoid environmental issues must be extended to the uranium ore mining and nuclear fuel production [6-8].

Spent nuclear fuel (SNF) will be stored in an underground deep geological repository (DGR). We expect that the barriers protecting the HLRW will be ineffective after a time period of the order of thousands of years [9] after closure. At this moment, groundwater will enter in contact with the waste and the reducing conditions in the DGR will not be preserved. An oxidative environment will appear in a layer near the SNF surface having a thickness of about $50 \mu \mathrm{m}$ [10]. The concentration of oxidized species as hydrogen peroxide [11] near the SNF surface will augment because of the radiolysis of water originated by the intense alpha radiation produced by the SNF [12-15]. Uranium in the matrix of the SNF then oxidizes from U(IV) to U(VI) and dissolves into the water forming uranyl groups $\left(\mathrm{UO}_{2}^{2+}\right)$. Secondary phases, that is, alteration products, on the spent fuel surface will appear due to the precipitation of these uranyl groups. The composition of these secondary phases will depend on the local physico-chemical conditions (mainly the $\mathrm{pH}$ and electrochemical potential) and the concentrations of reactive species present [16].

The secondary phases of SNF are more easily studied by analyzing natural uranyl-containing minerals [17] found as alteration products of uraninite [18], since this mineral is a natural analogue of the SNF matrix. The different alteration products of natural uraninites and its paragenetic sequence under different geochemical conditions were first described by Frondel [19, 20], and it is still widely accepted nowadays [16, 18, 21-24]. In this sequence, the uranyl oxide hydrates appear first, then the uranyl silicates and, less frequently, the uranyl phosphates, although the specific alteration products depend on the local conditions. Uranyl carbonates may precipitate where the evaporation is significant, and the carbon dioxide partial pressure is large $[17,25]$.

The release and the concomitant environmental impact of the fission products and transuranic elements present in the SNF to the biosphere $[8,26-41]$ can be diminished by retention processes of these contaminants in the crystal structures of these secondary phases. The precise knowledge of their unit cells $[27,28]$ is essential because it may be a used to understand and 
evaluate the incorporation of these elements into their crystal structures [8, 26-41]. Besides, the long-term performance assessment of DGRs requires the development of identification procedures and the characterization of the physical properties of these alteration products, which is a great challenge from the experimental point of view not only because these materials are very complicated involving the most elements of the periodic table but also due to its radiotoxicity [1].

An experimental technique is appropriate for the identification of uranyl-containing materials if fulfills the following demands [42]: (1) the samples do not require any special preparation; (2) the technique must allow the analysis of a very small amount of sample and, (3) it must be a non-destructive technique. X-ray diffraction [43] and Raman spectroscopic [44] techniques satisfy these criteria. Raman spectroscopy can differentiate among closely related compounds and provides structural information, but the extraction of this information requires a reliable assignment of the main bands in the Raman spectrum and models to interpret the values of the Raman shifts. Raman spectroscopy has been already used to characterize the secondary phases of SNF, but the nuclear Raman database is still under development. The excellent works performed by Frost et al. [45-51] should be underlined.

Theoretical solid-state calculations allow a safe and complete characterization of uranylcontaining materials free of the inconveniences associated to their radiotoxicity [42, 52-63]. However, the application of these methods to the study of mineral phases containing Rare Earth Elements is difficult not only due to the complexity of these materials but also to the high level of theory needed to describe these materials $[64,65]$. The number of valence electrons in the outer shells, which should be described explicitly, is very large and occupy high angular momentum orbitals. The inner electrons of these elements must be described by using relativistic pseudopotentials. Since an accurate pseudopotential specific for the uranium atom suitable for the realization of vibrational studies of solids was not available, a new norm-conserving relativistic pseudopotential was developed recently $[42,52]$. The use of this pseudopotential has permitted to perform a large series of studies about the crystal chemistry and bonding of the uranium atom in these systems.

The theoretical studies have allowed to confirm the crystal structures of many of these materials determined from X-ray diffraction data by structure refinement, which have never been studied using theoretical methods [54,55]. The knowledge of the crystal structures of uranylcontaining minerals has experienced a large improvement in the last times [24] due to the use of charge-coupled device (CCD) detectors for X-ray diffraction [66]. These detectors have allowed to perform reliable structural determinations of small size crystals and of materials comprising large unit cells, both cases being frequent for this kind of mineral phases. However, the determination of the hydrogen atom positions in many of these structures has not been possible. Two important examples are schoepite [56] and becquerelite phases [63]. The hydrogen atom positions in these structures were successfully determined theoretically $[56,63]$. The calculations were performed using theoretical solid-state methods based on density functional theory using plane waves and pseudopotentials [67].

Similarly, as was noted by Weck et al. [68,69], the existence of a great amount of information on the formation, thermodynamic stability, and phase transformations of alteration phases formed at the SNF surface is in contrast with the paucity of data regarding the mechanical 
stability and properties of these phases. This is surprising since the underlying atomistic deformation modes and interactions determine thermodynamic phase stability and transformation. Except the theoretical studies of Weck et al. [68,69] on the uranyl peroxide hydrates, studtite and metastudtite, and the studies of the mechanical behavior of uranium dioxide [70-72], no experimental or computational studies have reported the mechanical properties of these phases. Furthermore, the Born conditions of mechanical stability of the corresponding structures have not been analyzed. Whereas the lack of the experimental data could be related to the special care needed to handle these radioactive minerals, computational data have not been reported because of the difficulties in the application of theoretical methods to uranium-containing solids. However, from the computed structures, the mechanical properties and stability of rutherfordine, soddyite, uranophane, schoepite and becquerelite mineral phases were reported recently [54-56,63], based on the computed elasticity tensor. The elastic constant tensor of an inorganic compound provides a complete description of the response of the material to external stresses in the elastic limit [73] and is usually correlated with many mechanical properties such as the bulk and shear moduli, stiffness coefficients and anisotropy factors. The corresponding equations of state were also determined [54-56, 63].

Density Functional Perturbation Theory [74-76] allows the accurate determination of the vibrational Raman spectra with relatively small cost/performance ratios. Thus, although the computations required are generally quite expensive, these methods permit to perform a complete and rigorous assignment of the Raman vibrational bands. Whereas in the experimental works, the assignment is usually performed in an incomplete manner and by using empirical arguments, the theoretical methods provide graphical representations of the vibrational motions of the atoms in the corresponding normal modes. However, due to the lack of a good pseudopotential for uranium atom, there were very few published works on the theoretical vibrational spectra of uranium-containing solids [77-81] and the unique spectral features considered in these studies were the vibrational band wavenumbers.

This chapter provides mainly a review of the calculated structures, $\mathrm{X}$-ray and mechanical properties of uranyl-containing minerals. The computed structures, shown together, display the most common coordination structures of the uranium atom in these minerals and give a clear introduction to the crystal chemistry of uranyl ion. Furthermore, because there were not experimental values for a large fraction of the mechanical properties obtained in our previous works, the theoretical techniques were shown to have a highly predictive value. The data provided by these mechanical property calculations are within the most important mineral information, which is usually given to characterize a given mineral and the values reported together permit to extract the range of values which is likely to find for other uranyl-containing minerals. Finally, an example of the computed vibrational Raman spectrum for soddyite uranyl silicate mineral is provided to show the accuracy of the calculated spectra and how it was used to complement the experimental work in the assignment of the bands of the observed spectrum [54].

\section{Methods}

The generalized gradient approximation (GGA) together with PBE functional [82] supplemented with Grimme empirical dispersion correction [83], were used to study the soddyite, 
uranophane- $\alpha$ and schoepite mineral phases. The introduction of dispersion corrections improved significantly the computed structural and vibrational properties as a result of the better description of the hydrogen bonding present in the corresponding structures. For the case of rutherfordine mineral, the specialized version of PBE functional for solid materials, PBEsol [84], was used instead. These functionals are implemented in CASTEP program [85], a module of the Materials Studio package [86], which was employed to model the structures of the materials considered. The pseudopotentials used for $\mathrm{H}, \mathrm{C}, \mathrm{O}, \mathrm{Si}$, and $\mathrm{Ca}$ atoms in the unit cells of these minerals were standard norm-conserving pseudopotentials [87] given in CASTEP code (00PBE-OP type). The norm-conserving relativistic pseudopotential for $\mathrm{U}$ atom was generated from first principles as shown in previous works [42,52]. Whereas our uranium atom pseudopotential includes scalar relativistic effects, the corresponding pseudopotentials used for $\mathrm{H}, \mathrm{C}, \mathrm{O}, \mathrm{Si}$, and $\mathrm{Ca}$ atoms do not include them. This pseudopotential has been used extensively in the research of uranyl-containing materials [42, 52-63].

\subsection{Crystal structures and mechanical properties}

The atomic positions and cell parameters were optimized by using the Broyden-FletcherGoldfarb-Shanno method $[67,88]$ with a convergence threshold on atomic forces of $0.01 \mathrm{eV} / \AA$. The kinetic energy cut-off and k-point mesh [89] were chosen to ensure good convergence for computed structures and energies. The structures of the minerals considered in this work were optimized in calculations with augmented complexity by increasing these parameters. The precise calculation parameters used to determine the final results may be found in the corresponding articles [42, 53-56].

The elastic constants required to calculate the mechanical properties and to study the mechanical stability of the crystal structures were obtained from stress-strain relationships using the finite deformation method. Finite programmed symmetry-adapted strains [73] are used in this method to extract the individual constants from the stress tensor obtained as response of the system to the applied strains. This stress-based method was shown to be more efficient than the energy-based methods and the use of DFPT technique for the calculation of the elasticity tensor [90].

The elastic modulus and the corresponding derivatives with respect to pressure for the mineral phases rutherfordine, soddyite, uranophane- $\alpha$ and schoepite were calculated by fitting lattice volumes and associated pressures to a fourth-order Birch-Murnaghan equation of state (EOS) [91]. The lattice volumes near the equilibrium geometry were determined by optimizing the structure at several applied pressures with values in the range -1.0 and 12 GPa. EOSFIT 5.2 code [92] was used to adjust the results to the selected equation of state.

\subsection{Vibrational Raman spectra}

The vibrational spectra were calculated using the linear response density functional perturbation theory (DFPT) [74-76] implemented in the CASTEP code in the same way as in previous works $[42,54-57,93,94]$. The phonon frequencies at the gamma point of the Brillouin zone were determined using atomic displacement perturbations. Raman intensities are third-order derivatives of total energy with respect to atomic positions and laser electric field (twice). These are calculated in CASTEP [95] by using a combination of perturbation theory to evaluate 
the second derivatives with respect to applied fields and finite differences to evaluate the third derivatives with respect to atomic displacement. The frequencies presented in this work have not been scaled to correct for anharmonicity and remaining errors of the theoretical treatment employed, such as incomplete treatment of electron correlation and basis set truncation [96].

\section{Results and discussion}

The unit cell parameters and internal atomic positions were first optimized using initial atomistic models based in the atomic coordinates given by several authors [97-100]. From the optimized structures, we have obtained both the structural parameters as well as the X-ray powder patterns. Then, the mechanical properties, the EOS, the vibrational Raman spectrum and thermodynamic and optic properties were determined [42, 53-56].

\subsection{Crystal structures}

\subsubsection{Rutherfordine}

Christ et al. [101, 102] presented two possible orthorhombic structures for rutherfordine. The first is consistent with Pmmn symmetry and the second with Imm2 symmetry. The structure was later refined by Finch et al. [97]. We considered both orthorhombic structures for rutherfordine. The results found were nearly the same and the energy difference for the optimized structures was less than $0.001 \mathrm{eV}$. Therefore, only the results obtained for the Imm2 structure are described in detail here. The results for the Pmmn structure may be found in Ref. [42]. The results encountered [42] pointed that both structures may be simultaneously present in nature in accordance with the suggestion of Christ et al. [101, 102].

The computed structure of rutherfordine is shown in Figure 1A and B. It contains approximately linear $\mathrm{UO}_{2}^{2+}$ uranyl ions that are coordinated by six $\mathrm{O}$ atoms arranged at the equatorial vertices of uranyl hexagonal bipyramids. These $\mathrm{O}$ atoms belong to four carbonate ligands, and $U$ is bonded with two carbonate ions in a bidentate manner and two in a monodentate manner. Each uranyl polyhedron is linked to two other uranyl polyhedra in a trans arrangement by edge sharing, resulting in chains of polyhedra. Adjacent chains are linked by the sharing of equatorial vertices between uranyl polyhedra, which results in a sheet structure that contains triangular voids. Carbonate triangles occupy one half of the voids, such that they share the equatorial edges of two adjacent uranyl hexagonal bipyramids and single vertices of two additional uranyl polyhedra (see Figure 1A). The resulting sheets or layers are electroneutral, and adjacent sheets in rutherfordine are bonded together by van der Waals forces. The $\mathrm{UO}_{2} \mathrm{CO}_{3}$ layers are staggered with respect to the layer above or below, such that uranyl units lie above and below a carbonate carbon atom in adjacent layers. Layers are separated by a distance of about $4.6 \AA$. The structure is similar for Imm2 and Pmmn structures. For the Pmmn structure the carbonate triangles in contiguous sheets point in opposite directions while in the Imm2 one they point in the same direction (see Figure 1B, where two contiguous sheets in the structure of rutherfordine are shown). 


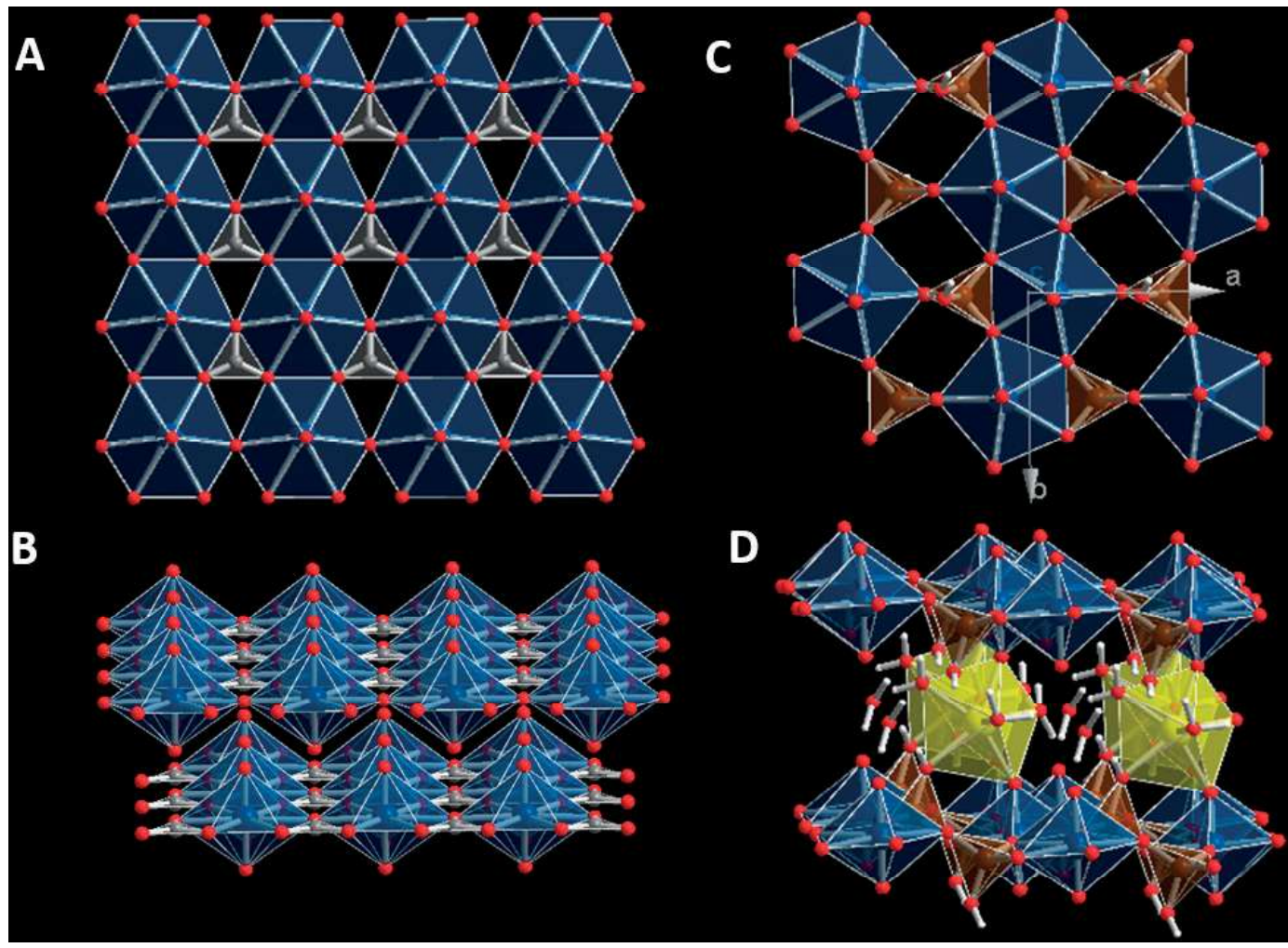

Figure 1. Structures of rutherfordine and uranophane- $\alpha$ minerals; (A) view of a sheet in the structure of rutherfordine from [010]; (B) two contiguous sheets in the structure of rutherfordine; (C) view of a $2 \times 2 \times 2$ supercell of uranophane- $\alpha$ from [001] showing a uranyl silicate sheet composed of $\mathrm{UO}_{7}$ pentagonal bipyramids and $\mathrm{SiO}_{3} \mathrm{OH}$ tetrahedra; (D) view of a $2 \times 2 \times 2$ supercell from [010] showing two uranyl silicate sheets connected by $\mathrm{CaO}_{2}(\mathrm{OH})\left(\mathrm{H}_{2} \mathrm{O}\right)_{4}$ polyhedra. One water molecule is out of the Ca coordination polyhedra (free water). Color code: $\mathrm{U}-$ blue, $\mathrm{O}-$ red, $\mathrm{C}-$ gray, $\mathrm{Ca}-$ yellow, $\mathrm{H}-$ white.

\subsubsection{Uranophane- $\alpha$}

The unit cell of uranophane- $\alpha$ has monoclinic symmetry [98]. Stohl and Smith [103] categorized naturally occurring uranyl silicates according to the uranium to silicon ratio, which in part determines the structures of these minerals. Most uranyl silicate minerals have 1:1 uranium to silicon ratio and are sheet silicates [27, 28, 98, 103]. Uranyl silicate sheets are composed of $\left[\left(\mathrm{UO}_{2}\right)_{2}\left(\mathrm{SiO}_{4}\right)_{2}\right]^{-4}$ units bound at the equatorial edges (see Figure $\left.1 \mathrm{C}\right)$. A sheet, $\left[\left(\mathrm{UO}_{2}\right)\left(\mathrm{SiO}_{4}\right)\right]_{n}{ }^{-2 \mathrm{n}}$, contains $\mathrm{UO}_{7}$ pentagonal bipyramids and $\mathrm{SiO}_{3} \mathrm{OH}$ tetrahedra. Charge compensating cations, calcium in uranophane, lie in the interlayer space between the sheets (see Figure 1D). Two uranyl silicate sheets are connected by $\mathrm{CaO}_{2}(\mathrm{OH})\left(\mathrm{H}_{2} \mathrm{O}\right)_{4}$ polyhedra (distorted pentagonal bipyramid). The $\mathrm{Ca}$ atom ligands are four water molecules, two uranyl oxygen atoms belonging to the upper and the lower sheets, and one $\mathrm{OH}$ group of $\mathrm{SiO}_{3} \mathrm{OH}$ tetrahedra. One water molecule is out of the Ca polyhedra. While this water molecule is described as free or crystallization water, the four water molecules belonging to the $\mathrm{Ca}$ atom coordination sphere are referred to as structural water. Hydrogen bonds reinforce the bonding between the uranyl silicate sheets, the Ca atom, and the free water. As it can be seen in Figure 1D, the upper sheet $\mathrm{SiO}_{3} \mathrm{OH}$ tetrahedra have free $\mathrm{OH}$ groups pointing downwards and the lower sheet tetrahedra have $\mathrm{OH}$ groups pointing upwards, which belong to the $\mathrm{Ca}$ atom coordination sphere. 


\subsubsection{Soddyite}

While most uranyl silicate minerals have 1:1 uranium to silicon ratio and are sheet silicates $[27,28,103]$, soddyite exhibits a 2:1 uranium to silicon ratio and framework crystal structure [99]. The computed structure is shown in Figure 2A and B. Figure 2A shows a view of the unit cell from [001]. Figure 2B is a view of a $2 \times 2 \times 1$ supercell along [110] where only a subset of atoms is retained in order to show a clearer view of the soddyite structure. As in the case of the other uranyl silicate considered, uranophane- $\alpha$, $U$ atoms display pentagonal bipyramid coordination, $\mathrm{UO}_{6}\left(\mathrm{H}_{2} \mathrm{O}\right)$, and $\mathrm{Si}$ atoms present tetrahedral coordination, $\mathrm{SiO}_{4}$. The $\mathrm{U}$ bipyramids are connected by sharing two non-adjacent edges of the equatorial plane to form zigzag chains (see Figure 2B). The single unshared equatorial vertex of the bipyramid is occupied by $\mathrm{H}_{2} \mathrm{O}$. All the water molecules are crystallization water, that is, belong to the coordination structure of uranium atom. The chains are parallel to [110] plane and are cross bonded through two opposite edges of the $\mathrm{SiO}_{4}$ tetrahedra; i.e. adjacent uranyl silicate chains are directly linked as each tetrahedron shares two edges with bipyramids from two different chains. Moreover, the cohesion of the structure is enhanced by a pattern of hydrogen bonds involving the water molecules and the uranyl $\mathrm{O}$ atoms.

\subsubsection{Schoepite}

The computed structure of schoepite is displayed in Figure 2C and $\mathbf{D}$. There are eight symmetrically distinct uranium sites in the structure of this mineral [100] (see Figure 2D). All $\mathrm{U}$ atoms are coordinated by seven anions in pentagonal bipyramidal arrangements. Each

A

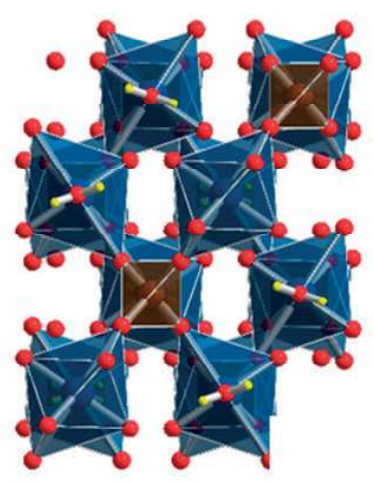

B

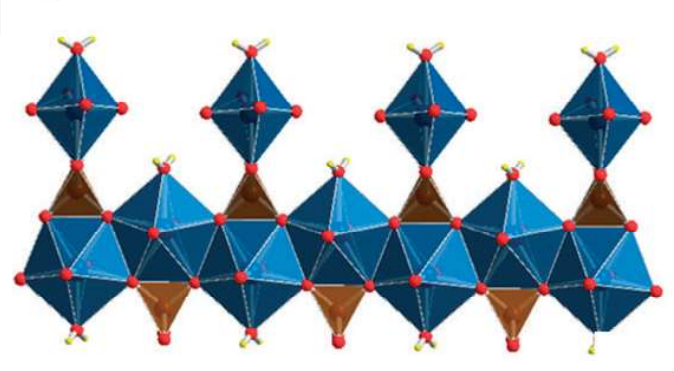

D
C
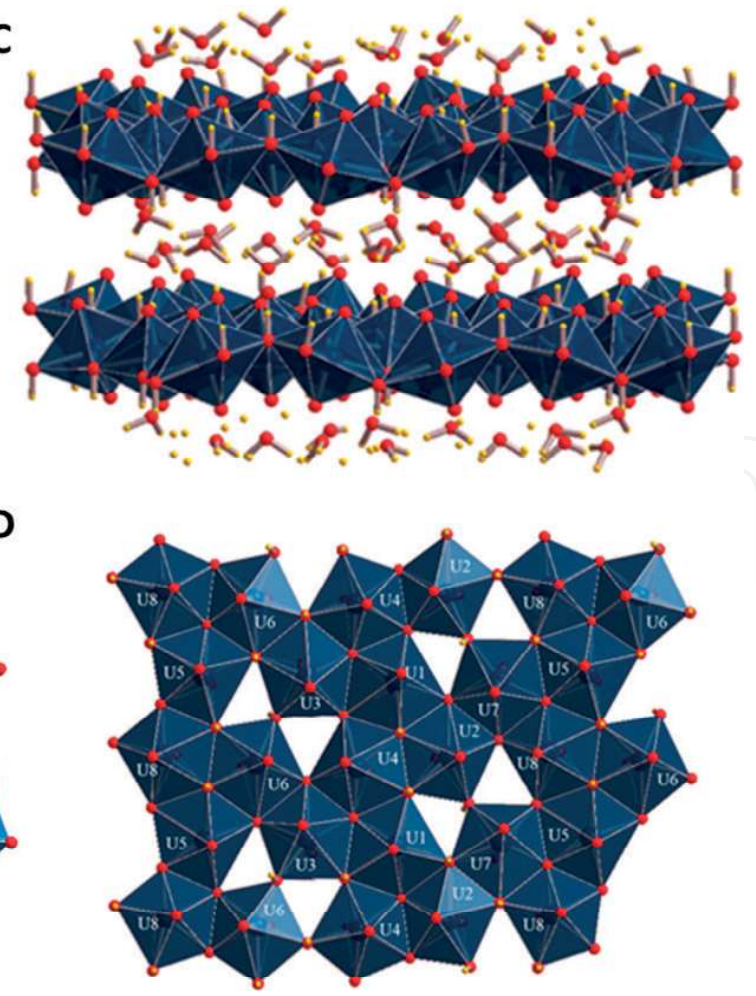

Figure 2. Structure of soddyite and schoepite minerals; (A) view of the unit cell of soddyite from [001]; (B) view of a $2 \times 2 \times 1$ supercell of soddyite from [110], retaining only a subset of atoms (a single chain of U bipyramids cross bonded to other chains through two opposite edges of the $\mathrm{SiO}_{4}$ tetrahedra is shown); (C) view of the full unit cell of schoepite from [100]; and (D) view of a schoepite sheet from [001] direction. Color code: U-blue, Si-brown, O-red, H-yellow. 
pentagonal bipyramid, referred to as $\mathrm{UO}_{7}$ below, consists of two apical $\mathrm{O}^{2-}$ anions and five equatorial anions, $\mathrm{O}^{2-}$ or $\mathrm{OH}^{-}$. While the uranium atoms $\mathrm{U} 2$ and $\mathrm{U} 6$ (see Figure 2D) have a coordination environment of $\mathrm{UO}_{2}(\mathrm{OH})_{5}$, the coordination for the remaining uranium atoms is $\mathrm{UO}_{2} \mathrm{O}(\mathrm{OH})_{4}$. The most stable configuration around a uranyl, $\mathrm{UO}_{2}^{2+}$ group has a pentagonal arrangement of equatorial anions as predicted for uranyl oxyhydroxides by Evans in 1963 [104]. The $\mathrm{UO}_{7}$ pentagonal bipyramids share edges to form dimers, which in turn, link by sharing edges to form staggered ribbons along the [100] direction. Then, these ribbons crosslink in the [010] direction by sharing edges and corners of the polyhedra. This results in a strongly bonded sheet of stoichiometry $\left[(\mathrm{UO})_{8} \mathrm{O}_{2}(\mathrm{OH})_{12}\right]$ parallel to plane $\{001\}$. This sheet constitutes the structural unit of schoepite, which stacks along the [001] direction. As the sheets are neutral, they are linked together by H-bonding only, through a complex network of $\mathrm{H}$-bonding involving interlayer $\mathrm{H}_{2} \mathrm{O}$ groups and $\mathrm{O}^{2-}$ or $\mathrm{OH}^{-}$groups in the structural sheet.

The structure within the uranium oxide hydroxide layers is basically the same in schoepite [100] metaschoepite [105] and many other uranium(VI) complex oxides, such as fourmarierite [106]. While most equatorial $\mathrm{O}^{2-}$ and $\mathrm{OH}^{-}$groups are shared as vertices of three $\mathrm{UO}_{7}$ polyhedra, the $\mathrm{O}$ atoms in some hydroxyl groups bridge two uranyl polyhedra alone [105]. The corresponding sections of the layers not occupied by the pentagons of the $\mathrm{UO}_{7}$ groups have a bow-tie-like motif (see Figure 2D) connected centrally at the bridging hydroxyl. There are $12 \mathrm{H}_{2} \mathrm{O}$ groups in schoepite interlayer. Ten of these $\mathrm{H}_{2} \mathrm{O}$ groups are located at the apices of two distorted pentagons and the remaining two water molecules are not members of the pentagonal rings and are located between the pentagonal rings. The pentagonal rings vertices are nearly at the positions of the equatorial anions in the U1 and U7 polyhedra from the two adjacent sheets. The general hydrogen bond structure described by Finch et al. [100] was properly reproduced by present theoretical calculations, confirming the suggested hydrogen bond structure. Besides, our results provided the locations for the hydrogen atoms in the full unit cell, which were never precisely obtained by either theoretical or experimental methods.

\subsubsection{Unit cell parameters}

As it has been mentioned in Section 2, the structures of these materials were determined in calculations with augmented complexity. Table 1 gives the final lattice parameters, volumes and densities obtained compared with the experimental ones [97-100]. As it can be seen, the theoretical calculations reproduce the experimental information accurately. The errors in the computed volumes and densities with respect to experimental data were very small, $0.1,0.3$, 0.4 and $2.1 \%$ for rutherfordine, soddyite, uranophane- $\alpha$ and schoepite, respectively.

\subsection{X-ray powder patterns}

The X-ray powder diffractograms of these minerals were calculated from the computed structures using $\mathrm{CuK}_{\alpha}$ radiation $(\lambda=1.540598 \AA)$. It must be outlined that the computation of the X-ray powder pattern of a given material does not require any additional optimization or response calculation. Their determination may be made directly from the optimized atomic positions and unit cell parameters [107]. The calculated patterns are compared in Figure 3 with the $X$-ray diffractograms computed from the experimental geometries of rutherfordine, soddyite and uranophane- $\alpha$ [97-99] (Figure 3A-C). The comparison of the 


\begin{tabular}{|c|c|c|c|c|c|c|c|c|c|}
\hline Material & Source & $a(\AA)$ & $b(\AA)$ & $c(\AA)$ & $\alpha$ & $\beta$ & $\gamma$ & Vol. $\left(\AA^{3}\right)$ & $\begin{array}{l}\text { Dens. } \\
\left(\mathrm{g} / \mathrm{cm}^{3}\right)\end{array}$ \\
\hline \multirow[t]{2}{*}{ Rutherfordine } & Calc. [42] & 4.8267 & 9.3639 & 4.2727 & 90 & 90 & 90 & 193.1 & 5.675 \\
\hline & Exp. [97] & 4.840 & 9.273 & 4.298 & 90 & 90 & 90 & 192.9 & 5.682 \\
\hline \multirow[t]{2}{*}{ Soddyite } & Calc. [54] & 8.0780 & 11.4253 & 18.8380 & 90 & 90 & 90 & 1738.6 & 5.104 \\
\hline & Exp. [99] & 8.334 & 11.212 & 18.668 & 90 & 90 & 90 & 1744.4 & 5.088 \\
\hline \multirow[t]{2}{*}{ Uranophane- $\alpha$} & Calc. [55] & 6.6689 & 7.0022 & 15.8684 & 90 & 98.07 & 90 & 733.7 & 3.8766 \\
\hline & Exp. [98] & 6.665 & 7.002 & 15.909 & 90 & 97.27 & 90 & 736.5 & 3.8618 \\
\hline \multirow[t]{2}{*}{ Schoepite } & Calc. [56] & 14.2740 & 16.8076 & 14.4841 & 90 & 90 & 90 & 3474.9 & 4.993 \\
\hline & Exp. [100] & 14.337 & 16.813 & 14.731 & 90 & 90 & 90 & 3550.9 & 4.886 \\
\hline
\end{tabular}

Table 1. Lattice parameters of rutherfordine, soddyite, uranophane- $\alpha$ and schoepite.

patterns derived directly from the structures is free of all possible interferences since both are determined under identical conditions. The agreement in line positions and intensities is very good. Nevertheless, the direct comparison of the calculated and experimental patterns was also very good [42, 54, 55]. Program XPowder [108] using the PDF-2 database [109] recognized the calculated spectra as those of the corresponding materials using low tolerance limits for the spectral differences. In the case of schoepite mineral, the X-ray powder spectrum was computed using REFLEX code included in Materials Studio package [86] and the results are compared in Figure 3D with the experimental X-ray diffractogram from the record 100188 of the RRUFF database [110] which corresponds to a natural schoepite mineral from Shinkolobwe mine, Katanga, Congo. The agreement of the computed and experimental diffractograms is excellent.

\subsection{Mechanical properties}

\subsubsection{Mechanical stability}

The elastic tensor, needed for the calculation of mechanical properties and to study the mechanical stability of a crystal structure, was calculated at the optimized equilibrium structure from stress-strain relationships, by using the finite deformation method implemented in CASTEP program. Materials with orthorhombic (rutherfordine, soddyite and schoepite) and monoclinic (uranophane- $\alpha$ ) unit cells have 9 and 13 non-degenerate elastic constants, $C(i, j)$ in the symmetric stiffness matrix $[68,73]$, respectively. The computed values of these constants are given in Refs. [53-56].

For orthorhombic systems, a set of necessary and sufficient Born [111, 112] conditions for mechanical stability are known $[68,113]$. These conditions can be expressed as a set of algebraic inequalities among products of elastic constants and were properly satisfied by the computed stiffness tensors of rutherfordine, soddyite and schoepite [53, 54, 56]. For monoclinic crystals, a set of necessary (but not sufficient) Born criteria for mechanical stability can also be written in terms of the stiffness matrix elements [68]. These conditions were fully satisfied by the computed elastic tensor of uranophane- $\alpha$ [55]. The generic necessary and sufficient 

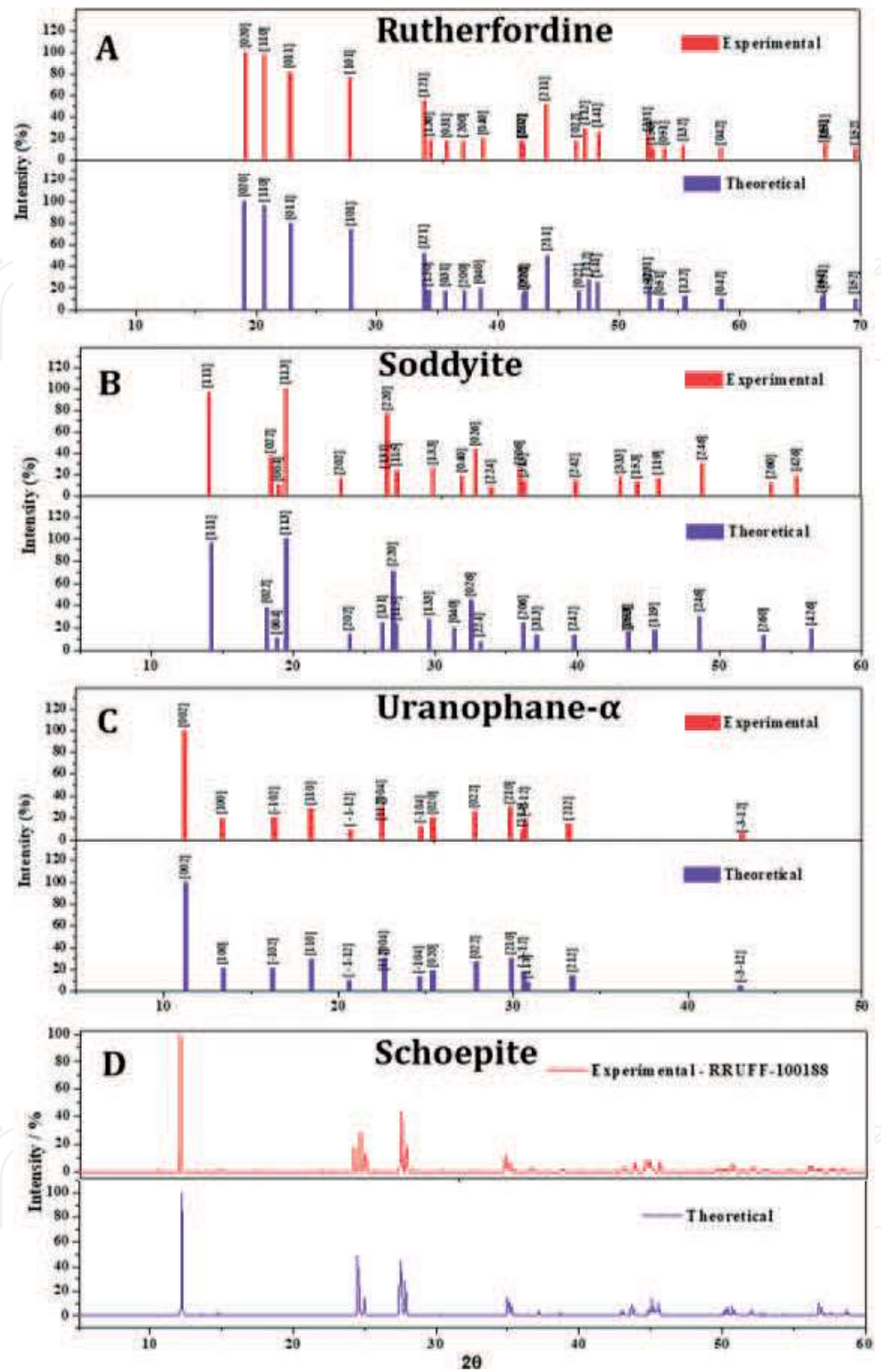

Figure 3. X-ray powder patterns of the materials under study using $\mathrm{CuK}_{\alpha}$ radiation: (A) rutherfordine; (B) soddyite; (C) uranophane- $\alpha$; and (D) schoepite.

Born criterion of stability is that all eigenvalues of the $C$ matrix be positive [113]. The $C$ matrix was diagonalized numerically, and all eigenvalues were found to be positive. Since the Born conditions were satisfied by the computed elastic tensors of all the materials studied, their mechanical stability was inferred [53-56]. 
The dynamical stability should also be analyzed to study the stability of the material in a complete form. A necessary and sufficient condition for the dynamical stability of a structure is that all of its phonon modes have positive frequencies for all wave vectors [113]. Since the fulfillment of this condition was also verified from the phonon calculations employed to determine the thermodynamic properties of these materials [53, 59, 62], their crystal structures were found to be mechanically and dynamically stable.

If the stiffness matrix of a material has a diagonal element associated to a certain direction which is much smaller than the other ones, it may be suggested that the thermal expansion of the material will occur predominantly along this direction. This feature was found to occur in the case of rutherfordine, uranophane- $\alpha$ and schoepite $[53,55,56]$ all of them being layered uranylcontaining minerals, along the direction perpendicular to the sheets characterizing their structures. This is consistent with the fact that the intersheet space in layered materials increase to a large extent as temperature increases due to the fact that the sheets are generally bonded only by weak van der Waals forces (rutherfordine [53]) or by hydrogen bonding among the sheets and water molecules present in their interlayer space (uranophane- $\alpha$ and schoepite $[55,56]$ ).

\subsubsection{Mechanical properties}

If single crystal samples are not available, the measurement of the individual elastic constants is not possible. Instead, the polycrystalline bulk modulus (B) and shear modulus (G) may be determined experimentally. The Voigt [114] and Reuss [115] schemes were used to compute the isotropic elastic properties of polycrystalline aggregates of these materials [53-56]. In Voigt method for calculating the elastic moduli, the strain throughout the aggregate of crystals is considered uniform, and the relations expressing the stress are averaged over all possible lattice orientations. While the strain is assumed to be uniform throughout the aggregate of crystals in Voigt's method, Reuss approximation considers the stress to be uniform and the averaging of the relations expressing the strain is carried out. As shown by Hill [116], the Reuss and Voigt approximations result in lower and upper limits, respectively, of polycrystalline constants and practical estimates of the polycrystalline bulk and shear moduli in the Hill approximation can be computed using average formulas. The formulae for these approximations may be found in several sources $[68,117]$. Although the differences between the results obtained for rutherfordine, soddyite and schoepite in the Reuss and Voigt approximations was generally small, this difference was found to be quite large for rutherfordine. This reason for this behavior is that rutherfordine is a highly anisotropic material showing large differences between the values of the elastic constants along different directions $[53,68]$.

The Reuss scheme provided the best results when the computed bulk moduli were compared with that determined from the equation of state (EOS) as it occurred in other works by other authors $[118,119]$. In the case of uranophane- $\alpha$, the Hill approximation gave the best results [55]. The values of the mechanical properties computed in in the Reuss approximation for rutherfordine, soddyite and schoepite and in the Hill approximation for uranophane- $\alpha$, are given in Table 2. CASTEP code gave a numerical estimate of the error in the computed bulk moduli, B, of $0.94,2.31,2.45$ and 2.28 GPa for rutherfordine, soddyite, uranophane and schoepite, respectively, and, consequently, our final values of the bulk moduli computed from the elastic constants are, $17.97 \pm 0.94,58.41 \pm 2.31,59.20 \pm 2.45$ and $34.53 \pm 2.28 \mathrm{GPa}$, respectively. 


\begin{tabular}{lllll}
\hline Property & Rutherfordine & Soddyite & Uranophane- $\alpha$ & Schoepite \\
\hline B & 17.97 & 58.41 & 59.20 & 34.53 \\
G & 19.47 & 36.00 & 36.52 & 23.17 \\
E & 42.92 & 89.60 & 90.88 & 56.80 \\
$v$ & 0.10 & 0.24 & 0.24 & 0.23 \\
D & 0.92 & 1.62 & 1.62 & 1.49 \\
H & 9.47 & 6.24 & 6.33 & 4.88 \\
\hline
\end{tabular}

Table 2. Computed bulk, modulus, shear modulus, Young modulus, Poisson ratio, Pugh's ratio, and Vickers hardness $(B, G, E, v, D$, and H) for rutherfordine, soddyite, uranophane- $\alpha$ and schoepite [53-56].

While the elasticity theory is very well understood and mathematically well founded, it is difficult to visualize how the elastic properties vary with the strain orientation, except for the simplest cases of isotropic materials. In order to address this difficulty, the ElAM software of Marmier et al. [120] was used to obtain detailed tridimensional representations of the most important elastic properties, which are shown in Figure 4 for schoepite [56]. In Figure $4 \mathrm{~A}$, the property displayed is the inverse of the bulk modulus (the compressibility) instead of the bulk modulus. As it can be seen in Figure 4A, the vertical direction (c axis) is the most compressible one in accordance with the previous discussion on the results of the stiffness matrix $\mathrm{C}$ matrix. Also, it must be noted that the corresponding tridimensional representations of the elastic properties of metaschoepite mineral, including those of the shear modulus, are very similar to those reported in Figure 4. This means that although the dehydration from schoepite to metaschoepite leads to a change of space symmetry $[97,105]$ the transformation is not shear induced, as occurs for the dehydration of studtite to metastudtite [69]. This behavior is the expected one, since the structures of schoepite and metaschoepite are very similar, the main changes being the differences in the arrangements of the interlayer water molecules and associated hydrogen bonds [105].

In general, a large value of shear moduli is an indication of the more pronounced directional bonding between atoms. Shear modulus represents the resistance to plastic deformation while the bulk modulus represents the resistance to fracture [117, 121]. Young modulus defines the relationship between stress (force per unit area) and strain (proportional deformation) in a material, that is, $\mathrm{E}=\sigma / \varepsilon$. Pugh [122] introduced the proportion of bulk to shear modulus of polycrystalline phases $(\mathrm{D}=\mathrm{B} / \mathrm{G})$ as a measure of ductility from the interpretation of the shear and bulk modulus given above. The value separating ductile and brittle materials is 1.75 , i.e., if $\mathrm{D}>1.75$, the material behaves in a ductile manner, otherwise the material behaves in a brittle manner [68]. The Poisson ratio, $v$, can be also utilized to measure the malleability of crystalline compounds, and is closely related to the Pugh's ratio. The Poisson ratio is close to 0.33 (1/3) for ductile materials, while it is generally much less than 0.33 for brittle materials. As it can be seen for rutherfordine, soddyite, uranophane and schoepite we find ratios D of $0.92,1.62,1.62$, and 1.49, respectively. Similarly, the calculated Poisson ratios, $v$ are $0.10,0.24,0.24,0.23$, respectively. These values are smaller than 1.75 (D) and $0.33(v)$, corresponding to brittle materials. For comparison, studtite and metastudtite uranyl peroxide minerals were found to be ductile [68]. 


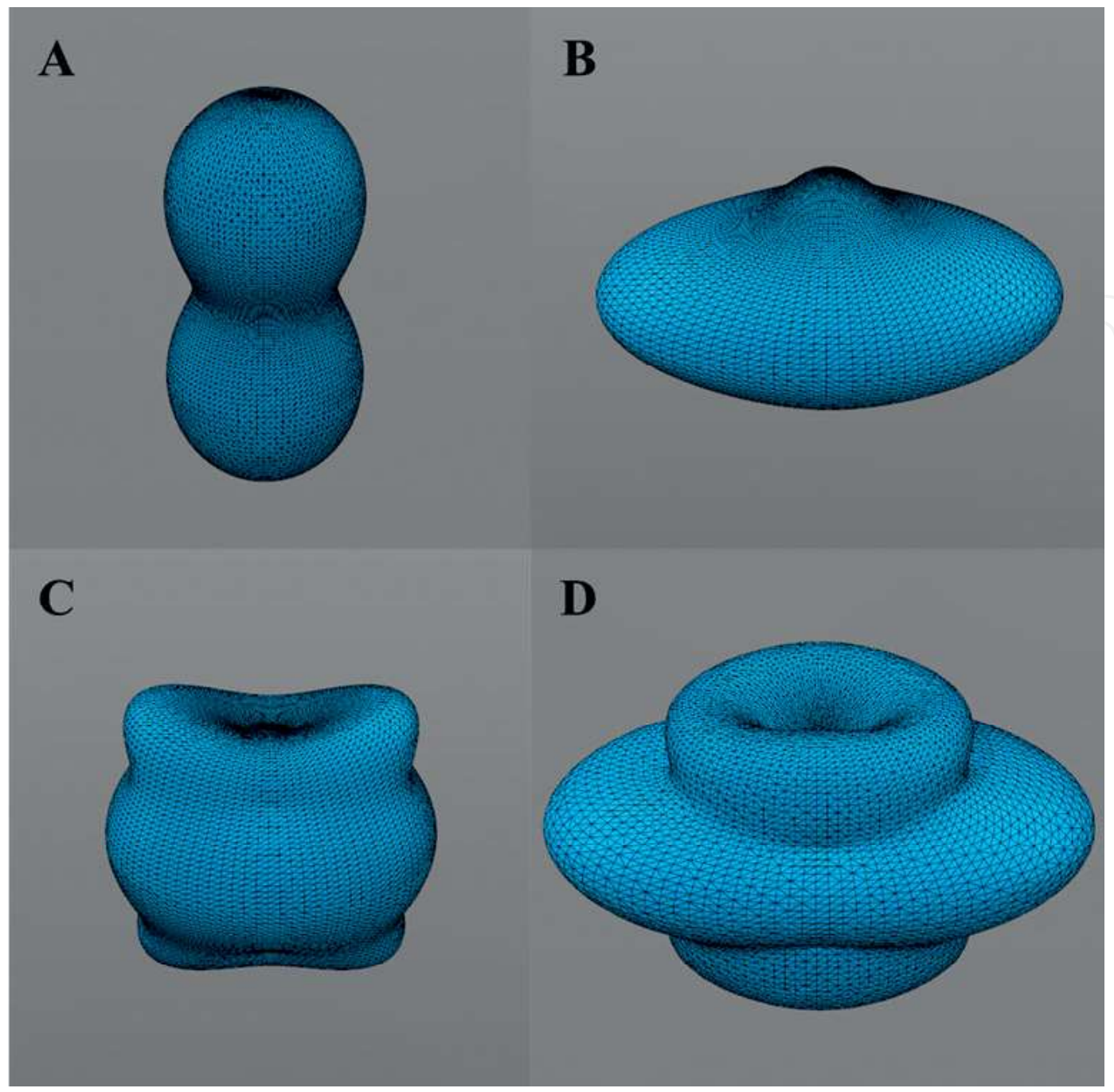

Figure 4. Schoepite elastic properties as a function of the orientation of the applied strain: (a) compressibility; (b) young modulus; (c) shear modulus; and (d) Poisson ratio.

Hardness of these systems is computed according to a recently introduced empirical scheme [123], which correlates the Vickers hardness and the Pugh's ratio ( $D=B / G)$. Vickers hardness, $\mathrm{H}$, values of polycrystalline rutherfordine, soddyite, uranophane and schoepite are given in Table 2. Rutherfordine is a material characterized by a quite large hardness, 9.5, and the three other materials have intermediate hardness values 6.2, 6.2, and 4.8. For comparison, we obtained the hardness of studtite and metastudtite [52] using the elasticity data of Weck et al. [68]. These systems, characterized by much larger D ratios, have much smaller hardness (smaller than one). The two uranyl silicates studied, uranophane and soddyite, have very similar hardness values of about $6.2[54,55]$.

In order to assess the elastic anisotropy of these minerals, shear anisotropic factors were obtained. These factors provide a measure of the degree of anisotropy in the bonding between atoms in different planes and are very important to study the material durability [117, 121]. Shear anisotropic factors for the $\{100\}\left(\mathrm{A}_{1}\right),\{010\}\left(\mathrm{A}_{2}\right)$, and $\{001\}\left(\mathrm{A}_{3}\right)$ crystallographic planes 
were computed. For an isotropic crystal, the factors $\mathrm{A}_{1^{\prime}}, \mathrm{A}_{2^{\prime}}$ and $\mathrm{A}_{3}$ must be one, while any value smaller or greater than unity is a measure of the degree of elastic anisotropy possessed by the crystal. For example, for uranophane [55], the computed anisotropy factors were $A_{1}=0.44<A_{2}$ $=0.51<\mathrm{A}_{3}=0.64$ and, consequently, the $\{100\}$ plane is shown to be the most anisotropic one.

The recently introduced universal anisotropy index [124], $\mathrm{A}^{\mathrm{U}}$, is another important measure of crystal anisotropy. The departure of $\mathrm{A}^{\mathrm{U}}$ from zero defines the extent of single crystal anisotropy and accounts for both the shear and the bulk contributions unlike all other existing anisotropy measures. Thus, $\mathrm{A}^{\mathrm{U}}$ represents a universal measure to quantify the single crystal elastic anisotropy. Rutherfordine, soddyite, uranophane, schoepite studtite and metastudtite are characterized by universal anisotropy indices of 8.81, 0.50, 0.81, 0.78, 2.17 and 1.44 [53-56, 68]. Therefore, while rutherfordine is strongly anisotropic [53] and studtite and metastudtite have quite large anisotropies [68], soddyite, uranophane and schoepite have very small anisotropies [54-56] ( $\mathrm{A}^{\mathrm{U}}=0$ corresponds to a perfectly isotropic crystal).

A set of fundamental physical properties may be estimated with the calculated elastic constants. For example, $\mathrm{V}_{\mathrm{L}}$ and $\mathrm{V}_{\mathrm{T}}$, the transverse and longitudinal elastic wave velocities in the polycrystalline materials may be determined in terms of the bulk and shear moduli [68]. The values obtained are presented in Table 3.

\subsubsection{Equations of state}

Unit cell volumes were determined by calculating the optimal structures at 17 different applied pressures between -1.0 and $12.0 \mathrm{GPa}$. The computed volume and pressure values were fitted to fourth-order Birch-Murnaghan [91] equations of state (EOS) by employing the EOSFIT 5.2 program [92]. The values found for bulk modulus and its first and second derivatives, respectively, at the temperature of $0 \mathrm{~K}\left(\mathrm{~B}, \mathrm{~B}^{\prime}\right.$, and $\left.\mathrm{B}^{\prime \prime}\right)$ are given in Table 4 . The corresponding values of the

\begin{tabular}{lllllll}
\hline Velocity component & Rutherfordine & Soddyite & Uranophane & Schoepite & Studtite & Metastudtite \\
\hline VT $(\mathrm{km} / \mathrm{s})$ & 2.367 & 2.708 & 3.069 & 2.217 & 1.74 & 1.69 \\
VL $(\mathrm{km} / \mathrm{s})$ & 3.820 & 4.671 & 5.276 & 3.759 & 3.31 & 3.50 \\
\hline
\end{tabular}

Table 3. Transverse and longitudinal elastic wave velocities of rutherfordine, soddyite, uranophane, schoepite studtite and metastudtite [53-56, 68].

\begin{tabular}{lllll}
\hline Property & Rutherfordine & Soddyite & Uranophane & Schoepite \\
\hline $\mathrm{B}(\mathrm{GPa})$ & $19.03 \pm 0.36$ & $60.07 \pm 0.67$ & $59.96 \pm 2.1$ & $35.17 \pm 0.39$ \\
$\mathrm{~B}^{\prime}$ & $15.34 \pm 0.72$ & $4.19 \pm 0.60$ & $2.29 \pm 1.11$ & $7.39 \pm 0.40$ \\
$\mathrm{~B}^{\prime \prime}\left(\mathrm{GPa}^{-1}\right)$ & $-7.43 \pm 1.32$ & $0.25 \pm 0.20$ & $-0.25 \pm 0.19$ & $-1.31 \pm 0.22$ \\
\hline
\end{tabular}

Table 4. Bulk modulus and its first and second derivatives at the temperature of $0 \mathrm{~K}\left(\mathrm{~B}, \mathrm{~B}^{\prime}\right.$, and $\left.\mathrm{B}^{\prime \prime}\right)$ for rutherfordine, soddyite, uranophane and schoepite [53-56] determined from fits to a fourth-order Birch-Murnaghan EOS. 


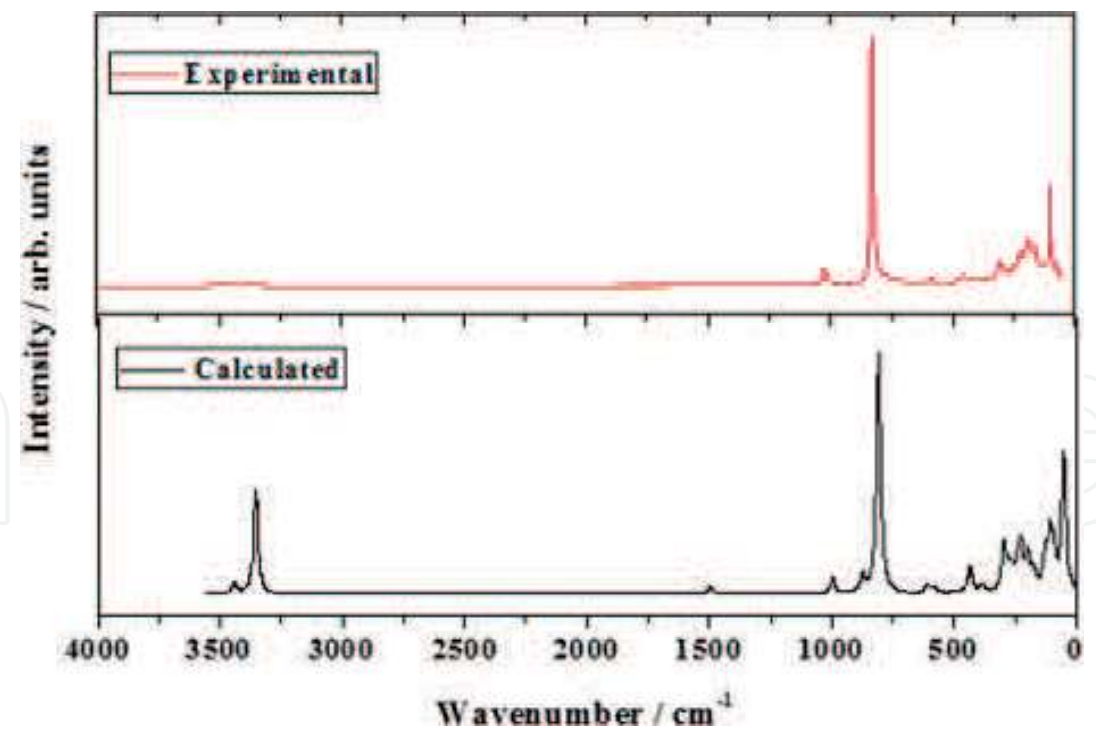

Figure 5. Experimental and calculated Raman spectra of soddyite mineral [54].
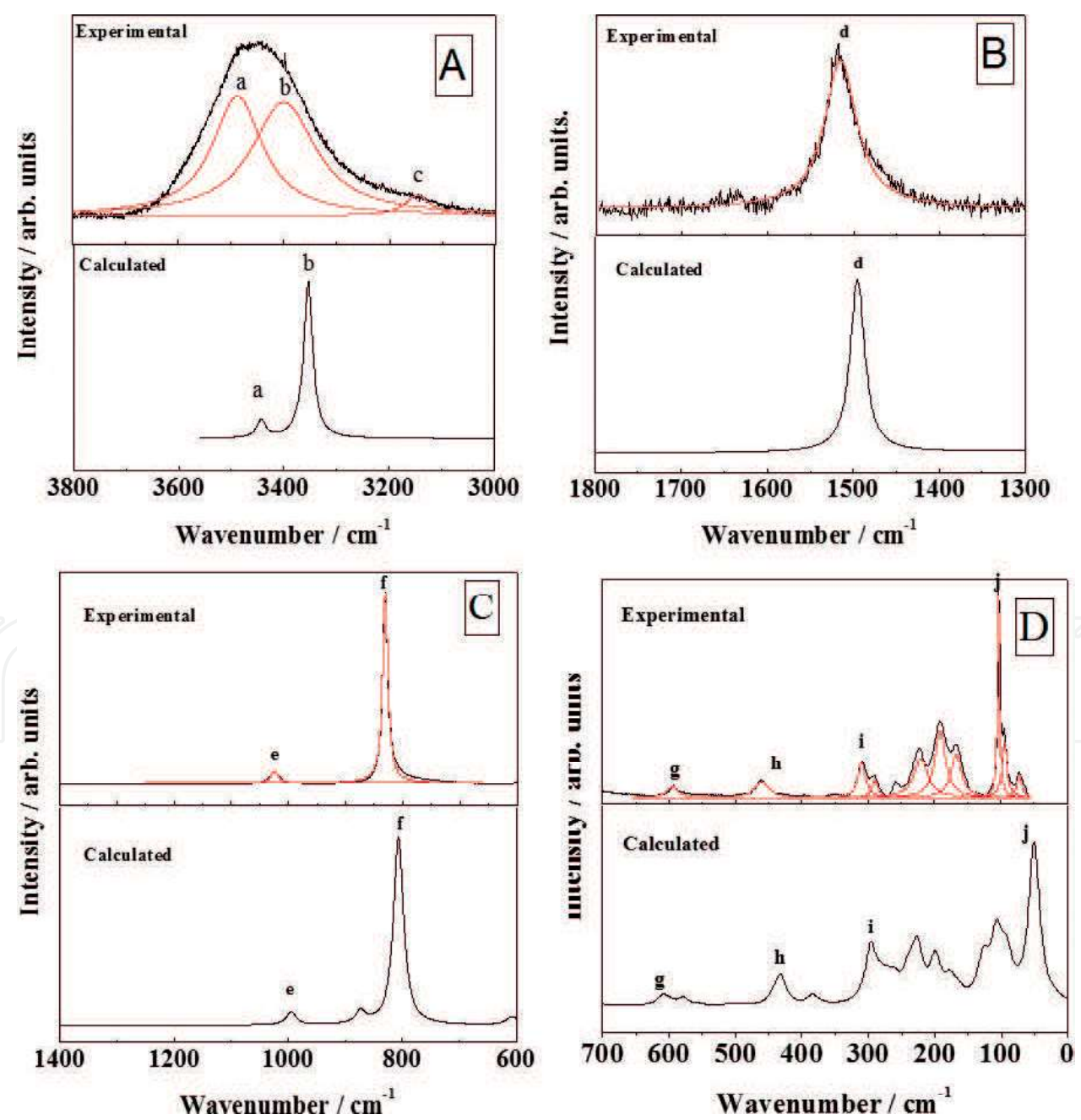

Figure 6. Experimental and theoretical Raman spectra of soddyite mineral. (A) Region: 3800-3000 $\mathrm{cm}^{-1}$; (B) region: $1800-1300 \mathrm{~cm}^{-1}$; (C) region: $1400-700 \mathrm{~cm}^{-1}$; (D) region: $700-0 \mathrm{~cm}^{-1}$. 
bulk modulus of rutherfordine, soddyite, uranophane and schoepite obtained from the elastic constants are $17.97 \pm 0.94,58.41 \pm 2.31,59.20 \pm 2.45$ and $34.53 \pm 2.28 \mathrm{GPa}$, respectively [53-56].

\subsection{Vibrational Raman spectra}

The vibrational Raman spectrum of soddyite was computed using DFPT and fully assigned [54]. In this section, we will provide a brief resume of the results obtained in order to show a representative example of the theoretical procedure used to characterize this mineral phase and assign the main bands in its Raman spectrum.

The Raman spectrum recorded in the wavenumber range of $3600-0 \mathrm{~cm}^{-1}$ is compared with the one obtained theoretically in Figure $\mathbf{5}$ and, as it may be observed, the calculated spectrum resembles closely the experimental one. The calculated spectrum was determined at ambient temperature using a laser radiation wavelength of $532 \mathrm{~nm}$ and a full width at half maximum of $20 \mathrm{~cm}^{-1}$.

The number of contributions of a given band in the experimental spectrum was obtained by using the second derivative method $[42,54]$. In Figure 6, the experimental and theoretical Raman spectra are displayed in four zones: (A) $\mathrm{OH}$ stretching vibration region from 3800 to $3000 \mathrm{~cm}^{-1}$ (Figure 6A); (B) $\mathrm{H}_{2} \mathrm{O}$ bending region 1800-1300 $\mathrm{cm}^{-1}$ (Figure 6B); (C) uranyl $\mathrm{UO}_{2}^{2+}$ and silicate $\mathrm{SiO}_{4}^{4-}$ fundamental vibrations region from 1400 to $700 \mathrm{~cm}^{-1}$ (Figure 6C); and (D) low wavenumber region from 700 to $0 \mathrm{~cm}^{-1}$ (Figure 6D). The wavenumbers of both spectra and the computed intensities and assignments are given in Table 5. The Raman shift values and assignments performed by Frost et al. $[45,48]$ are also provided in the table. The results obtained in each region are described separately in what follows.

a. $\mathrm{OH}$ stretching vibrations region. In this region, we found one broad band with two contributing bands placed at about 3488 and $3398 \mathrm{~cm}^{-1}$. The corresponding calculated Raman shifts were 3443 and $3353 \mathrm{~cm}^{-1}$. These two bands were attributed to antisymmetric and symmetric water stretching vibrations, respectively. Although the difference of computed and experimental shifts is quite large, it should be noted that the infrared $\mathrm{OH}$ stretching frequencies determined for isolated uranyl silicate clusters have much larger errors in comparison with the experimental data [125]. The low intensity band at wavenumber $3147 \mathrm{~cm}^{-1}$ is not found in the calculated spectrum. This band was also found by Frost et al. [46] at $3158 \mathrm{~cm}^{-1}$ and it is probably an overtone band $\left(2 v_{1}, v_{1}=1584 \mathrm{~cm}^{-1}\right)$ $[93,94]$.

b. $\mathrm{H}_{2} \mathrm{O}$ bending vibration region. The wavenumber obtained for the water bending vibration, was found at about $1584 \mathrm{~cm}^{-1}$, comparable to the computed value of $1495 \mathrm{~cm}^{-1}$. Frost et al. $[45,48]$ encountered an additional shoulder placed at $1596 \mathrm{~cm}^{-1}$. This was ascribed to water absorbed on the sample surface [54].

c. Uranyl $\mathrm{UO}_{2}^{2+}$ and silicate $\mathrm{SiO}_{4}^{4-}$ fundamental vibration regions. The experimental band at $1024 \mathrm{~cm}^{-1}$, is associated to the one calculated at $995 \mathrm{~cm}^{-1}$, which was assigned to the $\mathrm{SiO}_{4}^{4-}$ asymmetric stretching vibration. This vibration is shown in Figure 7A. Similar values for the wavenumber of this band were found by Frost et al. [45, 48] and Biwer et al. [126] (1025 and $1018 \mathrm{~cm}^{-1}$, respectively). The most intense band in the observed Raman spectrum is located about $830 \mathrm{~cm}^{-1}$ and computed at $807 \mathrm{~cm}^{-1}$. This band was found to be placed at 824 
and $828 \mathrm{~cm}^{-1}$ by Biwer et al. [126] and Frost et al. [48], respectively. As it can be observed in Figure $7 \mathbf{B}$, it must be assigned to uranyl symmetric stretching vibrations. There are two very close bands in the theoretical spectrum at 874 and $873 \mathrm{~cm}^{-1}$. Frost et al. [48] also encountered a pair of bands in this region at 909 and $897 \mathrm{~cm}^{-1}$, which were assigned to uranyl symmetric stretching vibrations. From in our theoretical results, we believe that the band at $909 \mathrm{~cm}^{-1}$ should be associated to the computed band at $873 \mathrm{~cm}^{-1}$, which is assigned to symmetric stretching silicate vibrations. Frost et al. [48] also found a band at $791 \mathrm{~cm}^{-1}$, which was assigned it to water librational vibrations. This band, however, is close to the computed one at $799 \mathrm{~cm}^{-1}$, which is attributed to uranyl symmetric stretching vibrations.

d. Low wavenumber region. The theoretical bands placed at 610 and $579 \mathrm{~cm}^{-1}$ can be compared with the experimental one located at $592 \mathrm{~cm}^{-1}$. These bands are attributed to water librational vibrations (twisting and rocking, respectively). Frost et al. [48], assigned the $591 \mathrm{~cm}^{-1}$

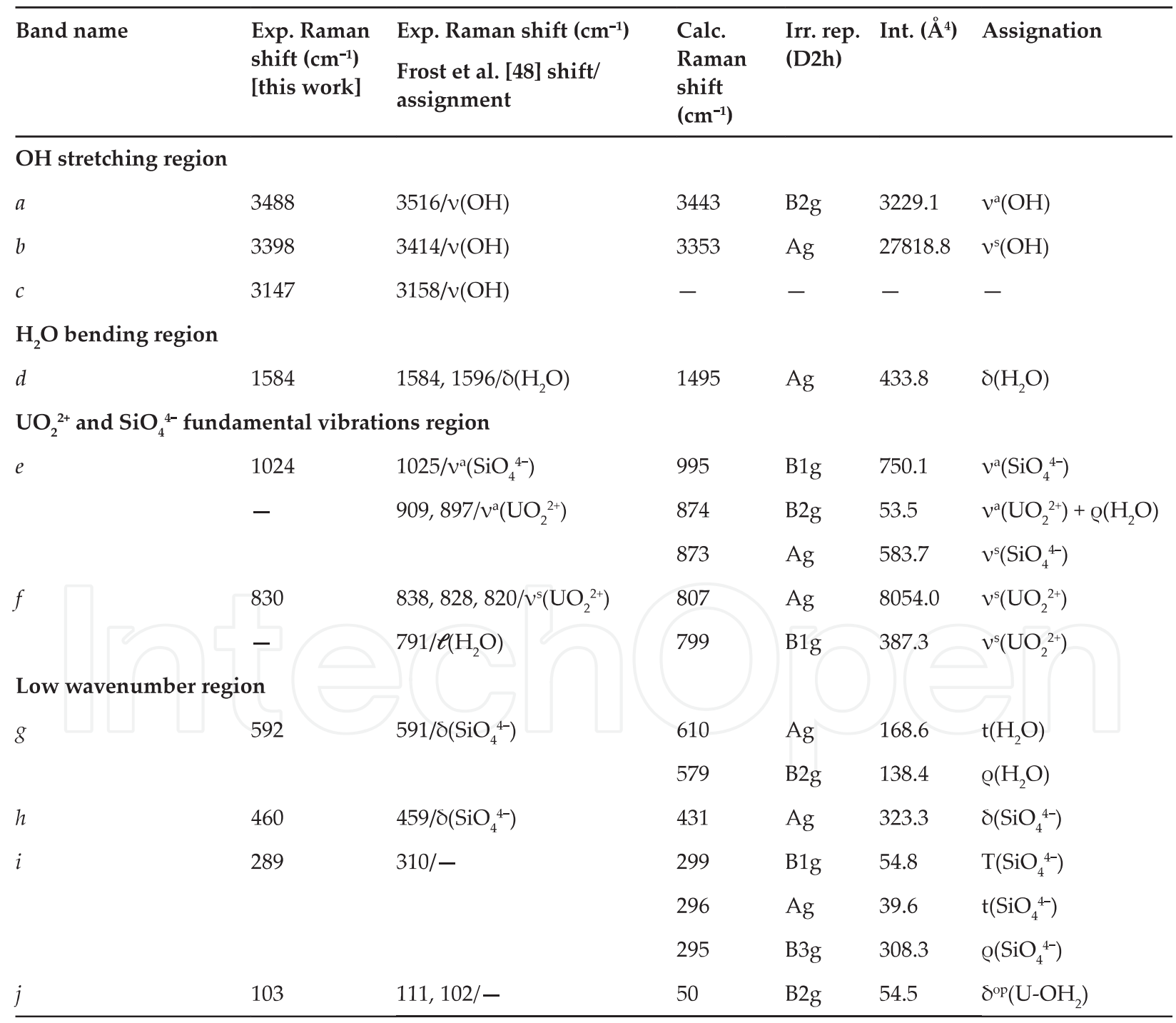

Table 5. Experimental and calculated Raman band wavenumbers, calculated intensities and assignments. Raman shifts and assignments performed by Frost et al. [48] are also given in the table. 

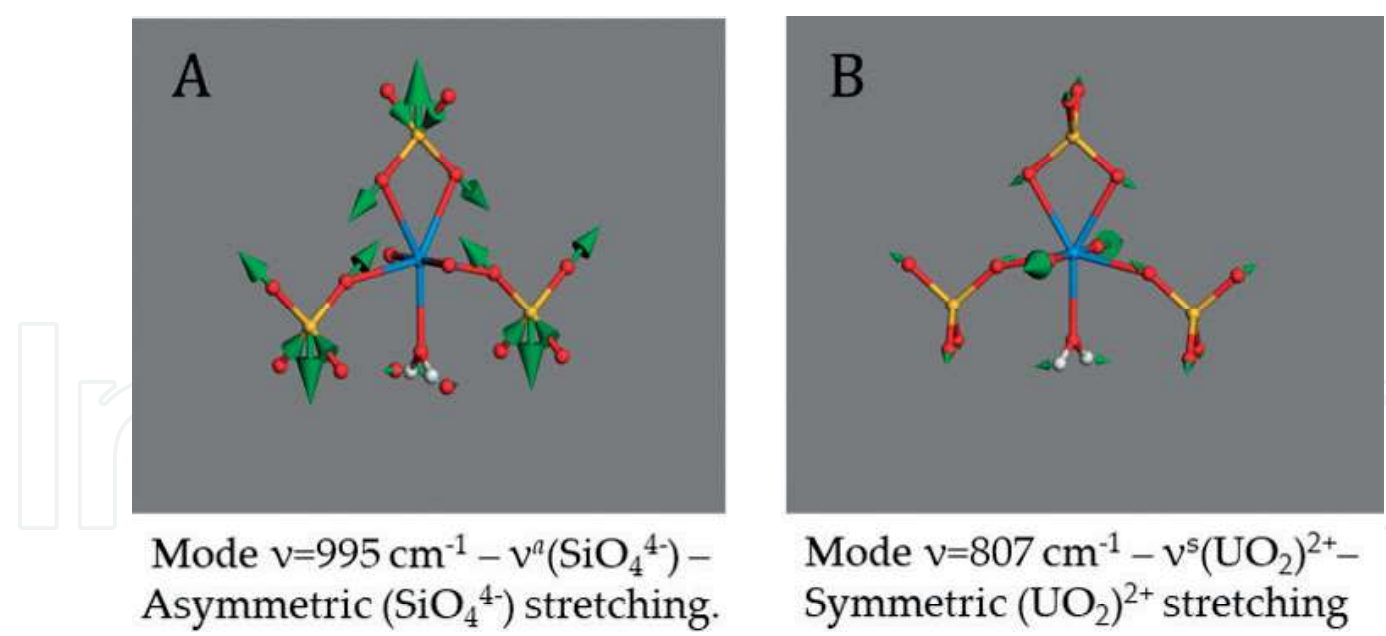

Figure 7. Pictures of the vibrational motions of the atoms is some Raman active normal modes of soddyite [54].

band to silicate bending vibrations. This last type of vibration is found in the computed spectrum at the wavenumber of $431 \mathrm{~cm}^{-1}$, which can be compared to the observed band at $460 \mathrm{~cm}^{-1}$. The wavenumbers of this band encountered by Biwer et al. [126] and Frost et al. [48], were 457 and $459 \mathrm{~cm}^{-1}$, respectively. While Biwer et al. [126], assigned this band to equatorial uranium-oxygen stretching vibrations, Frost et al. [48], ascribed it to silicate bending vibrations. The last assignment agrees with our assignment. The free silicate ion value for this vibration is $527 \mathrm{~cm}^{-1}$ [54]. The theoretical bands situated at 299, 296 and $295 \mathrm{~cm}^{-1}$ were mainly assigned to a silicate translation the first, and the other ones to different silicate deformation vibrations (twisting and rocking). They can be compared to the observed band placed at $289 \mathrm{~cm}^{-1}$. Finally, the low wavenumber theoretical band situated at $50 \mathrm{~cm}^{-1}$ can be approximately mapped to the experimental shift of $103 \mathrm{~cm}^{-1}$.

\section{Conclusions}

The results presented in the published papers [42,53-63] show that the theoretical computations are an extremely powerful tool in the research of uranium-containing compounds. Once the proper relativistic norm-conserving pseudopotential has been generated [42,52], the structural information, the X-ray powder patterns, the vibrational Raman spectra and mechanical and thermodynamic properties of these substances can be determined. This result is very significant because, if we have access to the adequate computational resources, very accurate results can be obtained despite the large size of the systems and the fact that the level of theory required to describe them is very high $[64,65]$. The use of these methods is free of the difficulties of the experimental methods associated to the radiotoxicity of these compounds requiring a careful management of the samples. Thus, the theoretical calculations allow the safe study of secondary phases of spent nuclear fuel in definitive disposal conditions. The natural samples used in the experimental studies are generally mixtures of several minerals and the theoretical treatment allows to study pure substances. Furthermore, the synthesis of these compounds is very complex and generally produces samples with low crystallinity. 
The theoretical solid-state methods may be used, in conjunction with experimental techniques, as an interpretative tool of the experimental structural and vibrational data or as a predictive tool to determine the structural, vibrational, mechanical and thermodynamic properties of these substances. The understanding of the structures of these compounds is very important itself to characterize them and to evaluate the possible incorporation of transuranic elements and fission products into the structures of uranyl minerals [8, 26-41]. The assignment of the main bands in the vibrational spectra of these compounds, performed usually by the experimentalist in an empirical way, can be made in a rigorous form since the theoretical methods produce microscopic scale views of the motion of the atoms in the corresponding normal vibrational states. In the systems studied the theoretical calculations has permitted the correct assignment of the bands of the full Raman spectrum for the first time. The main bands used to fingerprint these minerals were put into correspondence with specific structural data.

The calculated mechanical properties obtained for rutherfordine, soddyite and uranophane and schoepite minerals [53-56] have demonstrated the mechanical stability of their structures. Besides, a large amount of relevant mechanical data of these minerals were reported, including bulk modulus and its derivatives, elastic coefficients, shear and Young moduli, Poisson ratios, ductility and hardness indices, and elastic anisotropy measures. Their equations of state where also determined by fitting lattice volumes and pressures to a fourth order BirchMurnaghan equation of state. The importance of the availability of these mechanical data cannot be overlooked. The large volume expansion of the SNF resulting from SNF corrosion during storage $[127,128]$ will cause a very large stress upon the waste matrix and therefore the mechanical behavior of the waste components is extremely relevant.

\section{Acknowledgements}

This work has been carried out in the context of a CSIC-CIEMAT collaboration agreement: "Caracterización experimental y teórica de fases secundarias y óxidos de uranio formados en condiciones de almacenamiento de combustible nuclear". I also want to thank Dr. Rafael Escribano, Dr. Ana M. Fernández, Dr. Vicente Timón, Dr. Laura J. Bonales and Dr. Joaquín Cobos for their continuous help and advice during the realization of these studies.

\section{Conflict of interest}

The author declares that there is no conflict of interest.

\section{Dedication}

To my brother, TCR, on the occasion of his recent birthday. 


\section{Permissions}

Rutherfordine mineral. Figures 1A, $\mathbf{B}$ and $\mathbf{3 A}$ and data contained in Table $\mathbf{1}$ reproduced from Ref. [42] with permission from the PCCP Owner Societies. Data contained in Tables 2-4 reprinted (adapted) with permission from Ref. [53], Copyright (2017) American Chemical Society.

Uranophane- $\alpha$ mineral. Figures 1C, D and 3C and data contained in Tables 1-4 reproduced with the permission of the Mineralogical Society of Great Britain \& Ireland, from Ref. [55].

Soddyite mineral. Figures 2A, B, 3B, 5-7 and data contained in Tables 1-5 reprinted (adapted) with permission from Ref. [54], Copyright (2017) Elsevier.

Schoepite mineral. Figures 2C, D, 3D and 4 and data contained in Tables 1-4 reprinted (adapted) with permission from Ref. [56], Copyright (2018) American Chemical Society.

\section{Author details}

Francisco Colmenero Ruiz

Address all correspondence to: francisco.colmenero@iem.cfmac.csic.es

Instituto de Estructura de la Materia - Consejo Superior de Investigaciones Científicas (IEM-CSIC), Madrid, Spain

\section{References}

[1] Bruno J, Ewing RC. Spent nuclear fuel. Elements. 2006;2:343-349. DOI: 10.2113/gselements. 2.6.343

[2] Ewing RC. The nuclear fuel cycle: A role for mineralogy and geochemistry. Elements. 2006;2:331-334. DOI: 10.2113/gselements.2.6.331

[3] Ewing RC. Long-term storage of spent nuclear fuel. Nature Materials. 2005;14:252-256. DOI: $10.1038 /$ nmat4226

[4] Ewing RC, Weber WJ, Lian J. Nuclear waste disposal-Pyrochlore $\left(\mathrm{A}_{2} \mathrm{~B}_{2} \mathrm{O}_{7}\right)$ : Nuclear waste form for the immobilization of plutonium and "minor" actinides. Journal of Applied Physics. 2004;95:5949-5971. DOI: 10.1063/1.1707213

[5] Burns PC, Ewing RC, Navrotsky A. Nuclear fuel in a reactor accident. Science. 2012; 335:1184-1188. DOI: 10.1126/science.1211285

[6] Geipel G, Thieme M. Determination of inorganic species in seepage water of uranium mining rockpiles and in related media. Journal of Radioanalytical Inorganic Nuclear Chemistry. 1984;183:139-145 DOI: 0.1007/BF02043127 
[7] Abdelouas A. Uranium mill tailings: Geochemistry, mineralogy, and environmental impact. Elements. 2006;2:335-342. DOI: 10.2113/gselements.2.6.335

[8] Burns PC, Klingensmith AL. Uranium mineralogy and neptunium mobility. Elements. 2006;2:351-356. DOI: 10.2113/gselements.2.6.351

[9] Swedish Nuclear Fuel and Waste Management Co., SKB. Final Disposal of Spent Nuclear Fuel. Importance of the Bedrock for Safety. SKB Report 92-20; Stockholm: SKB; 1992

[10] Christensen H, Sunder S. An evaluation of layer water thickness effective in the oxidation of $\mathrm{UO}_{2}$ fuel due to radiolysis of water. Journal of Nuclear Materials. 1996;238:70-77. DOI: 10.1016/S0022-3115(96)00342-X

[11] Wang R, Katayama YB. Dissolution mechanisms for $\mathrm{UO}_{2}$ and spent fuel. Nuclear and Chemical Waste Management. 1982;3:83-90. DOI: 10.1016/0191-815X(82)90054-7

[12] Sattonnay G, Ardois C, Corbel C, Lucchini JF, Barthe MF, Garrido F, Gosset D. Alpharadiolysis effects on $\mathrm{UO}_{2}$ alteration in water. Journal of Nuclear Materials. 2001;288:11-19. DOI: $10.1016 / \mathrm{S} 0022-3115(00) 00714-5$

[13] Shoesmith DW. Fuel corrosion processes under waste disposal conditions. Journal of Nuclear Materials. 2000;282:1-31. DOI: 10.1016/S0022-3115(00)00392-5

[14] Sunder S. Calculation of radiation dose rates in a water layer in contact with used CANDU UO ${ }_{2}$ fuel. Nuclear Technology. 1998;122:211-221. DOI: 10.13182/NT98-A2863

[15] Roth O, Jonsson M. Oxidation of $\mathrm{UO}_{2}$ (s) in aqueous solution. Central European Journal of Chemistry. 2008;6:1-14. DOI: 0.2478/s11532-007-0067-z

[16] Plasil J. Oxidation-hydration weathering of uraninite: The current state-of knowledge. Journal of Geosciences. 2014;59:99-114. DOI: 10.3190/jgeosci.163

[17] Grenthe I, Drozdzynski J, Fujino T, Buck EC, Albrecht-Schmitt TE, Wolf SF. Uranium. In: Morss LR, Edelstein NM, Fuger J, editors. The Chemisty of Actinide and Transactinide Elements. Vol. 1. Berlin: Springer Science and Business Media; 2006. Chapter V. pp. 253-638. ISBN: 978-94-007-0211-0

[18] Finch RJ, Ewing RC. The corrosion of uraninite under oxidizing conditions. Journal of Nuclear Materials. 1992;190:133-156. DOI: 10.1016/0022-3115(92)90083-W

[19] Frondel C. Mineral composition of gummite. American Mineralogist. 1956;41:539-568. ISSN: 0003-004X

[20] Frondel C. Systematic mineralogy of uranium and thorium. U.S. Geological Survey Bulletin. 1958;1064:1-400. Available from: http://pubs.er.usgs.gov/publication/b1064ER [Accessed: 15-05-2018]

[21] Pearcy EC, Prikryl JD, Murphy WM, Leslie BW. Alteration of uraninite from the Nopal I deposit, Peña Blanca district, Chihuahua, Mexico, compared to degradation of spent 
nuclear fuel in the proposed US high-level nuclear waste repository at Yucca Mountain, Nevada. Applied Geochemistry. 1994;9:713-732. DOI: 10.1016/0883-2927(94)90030-2

[22] Wronkiewicz DJ, Bates JK, Gerding TJ, Veleckis E, Tani BS. Uranium release and secondary phase formation during unsaturated testing of $\mathrm{UO}_{2}$ at $90^{\circ} \mathrm{C}$. Journal of Nuclear Materials. 1992;190:107-127. DOI: 10.1016/0022-3115(92)90081-U

[23] Wronkiewicz DJ, Bates JK, Wolf SF, Buck EC. Ten-year results from unsaturated drip tests with $\mathrm{UO}_{2}$ at $90^{\circ} \mathrm{C}$ : Implications for the corrosion of spent nuclear fuel. Journal of Nuclear Materials. 1996;238:78-95. DOI: 10.1016/S0022-3115(96)00383-2

[24] Finch RJ, Murakami T. Systematics and paragenesis of uranium minerals. In: Ribbe PH, editor. URANIUM: Mineralogy, Geochemistry and the Environment; Reviews in Mineralogy. Vol. 38. New York: Mineralogical Society of America; 1999. pp. 91-180. ISBN: 0-939950-50-2

[25] Clark DL, Hobart DE, Neu MP. Actinide carbonte complexes and their importance in actinide environmental chemistry. Chemical Reviews. 1995;95:25-48. DOI: 10.1021/ cr00033a002

[26] Burns PC, Ewing RC, Miller ML. Incorporation mechanisms of actinide elements in to the structures of $\mathrm{U}^{6+}$ phases formed during the oxidation of spent nuclear fuel. Journal of Nuclear Materials. 1997;245:1-9. DOI: 10.1016/S0022-3115(97)00006-8

[27] Burns PC. The crystal chemistry of uranium. In: Ribbe PH, editor. Uranium: Mineralogy, Geochemistry and the Environment; Reviews in Mineralogy. New York: Mineralogical Society of America; 1999. pp. 23-90. ISBN: 0-939950-50-2

[28] Burns PC. $\mathrm{U}^{6+}$ minerals and inorganic compounds: Insights into an expanded structural hierarchy of crystal structures. The Canadian Mineralogist. 2005;43:1839-1894. DOI: 10.2113/gscanmin.43.6.1839

[29] Burns PC. The structure of Botwoodite and implications of solid solution towards sodium Boltwoodite. The Canadian Mineralogist. 1998;36:1069-1075. ISSN: 0008-4476

[30] Burns PC. Cs Boltwoodite obtained by ion exchange from single crystals: Implications for radionuclide release in a nuclear repository. Journal of Nuclear Materials. 1999;265:218223. DOI: $10.1016 / S 0022-3115(98) 00646-1$

[31] Burns PC, Li Y. The structures of becquerelite and Sr-exchanged becquerelite. American Mineralogist. 2002;87:550-557. DOI: 10.2138/am-2002-0418

[32] Klingensmith AL, Burns PC. Neptunium substitution in synthetic uranophane and soddyite. American Mineralogist. 2007;92:1946-1951. DOI: 10.2138/am.2007.2542

[33] Burns PC, Deely KM, Skanthakumar S. Neptunium incorporation into uranyl compounds that form as alteration products of spent nuclear fuel: implications for geologic repository performance. Radiochimica Acta. 2004;92:151-159. DOI: 10.1524/ract.92.3.151.30491

[34] Burns PC, Miller ML, Ewing RC. $\mathrm{U}^{6+}$ minerals and inorganic phases: A comparison and hierarchy of crystal structures. The Canadian Mineralogist. 1996;34:845-880. ISSN: 0008-4476 
[35] Burns PC, Ewing RC, Hawthorne FC. The crystal chemistry of hexavalent uranium: Polyhedron geometries, bond-valence parameters, and polymerization of polyhedra. The Canadian Mineralogist. 1997;35:1551-1570. ISSN: 0008-4476

[36] Douglas M, Clark SB, Utsunomiya S, Ewing RC. Cesium and strontium incorporation into uranophane, $\mathrm{Ca}\left[\left(\mathrm{UO}_{2}\right)\left(\mathrm{SiO}_{3} \mathrm{OH}\right)\right]_{2} \cdot 5 \mathrm{H}_{2} \mathrm{O}$. Journal of Nuclear Science and Technology Supplement. 2002;3:504-507. DOI: 10.1080/00223131.2002.10875517

[37] Douglas M, Clark SB, Friese JI, Arey BW, Buck EC, Hanson BD, Utsunomiya S, Ewing RC. Microscale characterization of uranium(VI) silicate solids and associated neptunium(V). Radiochimica Acta. 2005;93:265-272. DOI: 10.1524/ract.93.5.265.64281

[38] Murphy WM, Grambow B. Thermodynamic interpretation of neptunium coprecipitation in uranophane for application to the Yucca Mountain Repository. Radiochimica Acta. 2008;96:563-567. DOI: 10.1524/ract.2008.1537

[39] Shuller LC, Ewing RC, Becker U. Quantum-mechanical evaluation of Np-incorporation into studtite. American Mineralogist. 2010;95:1151-1160. ISSN: 0003-004X

[40] Shuller LC, Ewing RC, Becker U. Np-incorporation into uranyl phases: A quantummechanical evaluation. Journal of Nuclear Materials. 2013;434:440-450. DOI: 10.1016/j. jnucmat.2011.04.016

[41] Shuller LC, Bender WM, Walker SM, Becker U. Quantum-mechanical methods for quantifying incorporation of contaminants in proximal minerals. Minerals. 2014;4:690-715. DOI: $10.3390 / \min 4030690$

[42] Bonales LJ, Colmenero F, Cobos J, Timón V. Spectroscopic Raman characterization of rutherfordine: A combined DFT and experimental study. Physical Chemistry Chemical Physics. 2016;18:16575-16584. DOI: 10.1039/C6CP01510G

[43] Baker RJ. Uranium minerals and their relevance to long term storage of nuclear fuels. Coordination Chemistry Reviews. 2014;266-267:123-136. DOI: 10.1016/j.ccr.2013.10.004

[44] Dubessy J, Caumon MC, Rull F, editors. Raman Spectroscopy Applied to Earth Sciences and Cultural Heritage. EMU Notes in Mineralogy. Vol. 12. European Mineralogical Union; 2012. ISBN: 978-0-903056-34-2

[45] Frost RL, Čejka J. A Raman spectroscopic study of the uranyl carbonate rutherfordine. Journal of Raman Spectroscopy. 2007;38:1488-1493. DOI: 10.1002/jrs.1796

[46] Frost RL, Čejka J. A Raman spectroscopic study of the uranyl mineral rutherfordineRevisited. Journal of Raman Spectroscopy. 2009;40:1096-1103. DOI: 10.1002/jrs.2174

[47] Frost RL, Čejka J, Weier ML, Martens W. Molecular structure of the uranyl silicatesA Raman spectroscopic study. Journal of Raman Spectroscopy. 2006;37:538-551. DOI: 10.1002/jrs. 1430

[48] Frost RL, Čejka J, Weier ML, Martens W. A Raman and infrared spectroscopic study of the uranyl silicates -Weeksite, soddyite and haiweeite: Part 2. Spectrochimica Acta A. 2006;63:305-312. DOI: 10.1016/j.saa.2005.05.015 
[49] Frost RL, Čejka J, Weier ML. Raman spectroscopic study of the uranyl oxyhydroxide hydrates: becquerelite, billietite, curite, schoepite and vandendriesscheite. Journal of Raman Spectroscopy. 2007;38:460-466. DOI: 10.1002/jrs.1669

[50] Frost RL, Dickfos MJ, Čejka J. Raman spectroscopic study of the uranyl carbonate mineral zellerite. Journal of Raman Spectroscopy. 2008;39:582-586 DOI: 0.1002/jrs.1879

[51] Frost RL, Čejka J, Scholz R, López A, Theiss FL, Xi Y. Vibrational spectroscopic study of the uranyl selenite mineral derriksite $\mathrm{Cu}_{4} \mathrm{UO}_{2}\left(\mathrm{SeO}_{3}\right)_{2}(\mathrm{OH})_{6} \cdot \mathrm{H}_{2} \mathrm{O}$. Spectrochimica Acta A. 2014;113:473-477. DOI: 10.1016/j.saa.2013.08.026

[52] Colmenero F. Characterization of secondary phases of spent nuclear fuel under final geological disposal conditions [Ph.D. thesis]. Madrid: Universidad Autónoma de Madrid; 2017. 443 pp. DOI: 10.13140/RG.2.2.10526.43843

[53] Colmenero F, Bonales LJ, Cobos J, Timón V. Thermodynamic and mechanical properties of rutherfordine mineral based on density functional theory. Journal of Physical Chemistry C. 2017;121:5994-6001. DOI: 10.1021/acs.jpcc.7b00699

[54] Colmenero F, Bonales LJ, Cobos J, Timón V. Structural, mechanical and vibrational study of uranyl silicate mineral soddyite by DFT calculations. Journal of Solid State Chemistry. 2017;253:249-257. DOI: 10.1016/j.jssc.2017.06.002

[55] Colmenero F, Bonales LJ, Timón V, Cobos J. Structural, mechanical and Raman spectroscopic characterization of layered uranyl silicate mineral uranophane- $\alpha$ by DFT Methods. Clay Minerals. 2018. DOI: 10.1180/clm.2018.27

[56] Colmenero F, Cobos J, Timón V. Periodic DFT study of the structure, Raman spectrum and mechanical properties of schoepite mineral. Inorganic Chemistry. 2018;212:125-135. DOI: $10.1021 /$ acs.inorgchem. 8 b00150

[57] Colmenero F, Bonales LJ, Cobos J, Timón V. Study of the thermal stability of studtite by in situ Raman spectroscopy and DFT calculations. Spectrochimica Acta A. 2017;174:245253. DOI: $10.1016 /$ j.saa.2016.11.040

[58] Colmenero F, Bonales LJ, Cobos J, Timón V. Density functional theory study of the thermodynamic and Raman vibrational properties of $\gamma-\mathrm{UO}_{3}$ polymorph. Journal of Physical Chemistry C. 2017;121:14507-14516. DOI: 10.1021/acs.jpcc.7b04389

[59] Colmenero F, Fernández AM, Cobos J, Timón V. Thermodynamic properties of uranylcontaining materials based on density functional theory. Journal of Physical Chemistry C. 2018;122:5254-5267. DOI: 10.1021/acs.jpcc.7b12341

[60] Colmenero F. The application of periodic density functional theory to the study of uranyl containing materials: Thermodynamic properties and stability. In: Glossman-Mitnik D, editor. Density Functional Theory. London: InTechOpen; 2018. ISBN 978-953-51-7020-4

[61] Colmenero F, Fernández AM, Cobos J, Timón V. Temperature-dependent gibbs free energies of reaction of uranyl-containing materials based on density functional theory. Journal of Physical Chemistry C. 2018;122:5268-5279. DOI: 10.1021/acs.jpcc.7b12368 
[62] Colmenero F, Fernández AM, Cobos J, Timón V. Periodic DFT study of the thermodynamic properties and stability of schoepite and metaschoepite mineral phases. Physical Chemistry Chemical Physics. 2018 (under review)

[63] Colmenero F, Fernández AM, Cobos J, Timón V. Becquerelite mineral phase: crystal structure and thermodynamic and mechanic stability by using periodic DFT. RSC Advances. 2018;8:24599-24616. DOI: 10.1039/c8ra04678f

[64] Crocombette JP, Jollet F, Nga LT, Petit T. Plane-wave pseudopotential study of point defects in uranium dioxide. Physical Review B. 2001;64:104107. DOI: 10.1103/PhysRevB. 64.104107

[65] Beridze G, Kowalski PM. Benchmarking the DFT+U method for thermochemical calculations of uranium molecular compounds and solids. Journal of Physical Chemistry A. 2014;118:11797-11810. DOI: 10.1021/jp5101126

[66] Burns PC. CCD area detectors of X-rays applied to the analysis of mineral structures. The Canadian Mineralogist. 1998;36:847-853. ISSN: 0008-4476

[67] Payne MC, Teter MP, Ailan DC, Arias A, Joannopoulos JD. Iterative minimization techniques for $\mathrm{Ab}$ initio total-energy calculations: Molecular dynamics and conjugate gradients. Review of Modern Physics. 1992;64:1045-1097. DOI: 10.1103/RevModPhys.64.1045

[68] Weck PF, Kim E, Buck EC. On the mechanical stability of uranyl peroxide hydrates: Implications for nuclear fuel degradation. RSC Advances. 2015;5:79090-79097. DOI: 10.1039/C5RA16111H

[69] Weck PF, Kim E. Uncloaking the thermodynamics of the studtite to metastudtite shearinduced transformation. Journal of Physical Chemistry C. 2016;120:16553-16560. DOI: 10.1021/acs.jpcc.6b05967

[70] Fritz I. Elastic properties of $\mathrm{UO}_{2}$ at high pressure. Journal of Applied Physics. 1976;47:4353. DOI: $10.1063 / 1.322438$

[71] Ibrahim M, Castelier E, Palancher H, Bornert M, Care S, Micha JS. Mechanical behaviour near grain boundaries of He-implanted $\mathrm{UO}_{2}$ ceramic polycrystals. Journal of Nuclear Materials. 2017;483:13-20. DOI: 10.1016/j.jnucmat.2016.10.044

[72] Nguyen TH, Debelle A, Boulle A, Garrido F, Thomas L, Demange V. Mechanical response of $\mathrm{UO}_{2}$ single crystals submitted to low-energy ion irradiation. Journal of Nuclear Materials. 2015;467:505-511. DOI: 10.1016/j.jnucmat.2015. 10.046

[73] Nye JF. The Physical Properties of Crystals: Their Representation by Tensors and Matrices. New York: Oxford University Press; 1985. ISBN: 0198511655

[74] Baroni S, de Gironcoli S, Dal Corso SA. Phonons and related crystal properties from density-functional perturbation theory. Review of Modern Physics. 2001;73:515-562. DOI: $10.1103 /$ RevModPhys.73.515

[75] Gonze X, Lee C. Dynamical matrices, born effective charges, dielectric permittivity tensors, and interatomic force constants from density-functional perturbation theory. Physical Review B. 1997;55:10355-10368. DOI: 10.1103/PhysRevB.55.10355 
[76] Refson K, Tulip PR, Clark SJ. Variational density-functional perturbation theory for dielectrics and lattice dynamics. Physical Review B. 2006;73:155114. DOI: 10.1103/PhysRevB. 73.155114

[77] Yun Y, Legut D, Oppeneer PM. Phonon spectrum, thermal expansion and heat capacity of $\mathrm{UO}_{2}$ from first-principles. Journal of Nuclear Materials. 2012;426:109-114. DOI: 10.1016/j.jnucmat.2012.03.017

[78] Yin Q, Savrasov SY. Origin of low thermal conductivity in nuclear fuels. Physical Review Letters. 2008;100:225504. DOI: 10.1103/PhysRevLett.100.225504

[79] Wang BT, Zhang P, Lizárraga P, Di Marco I, Eriksson O. Phonon spectrum, thermodynamic properties, and pressure-temperature phase diagram of uranium dioxide. Physical Review B. 2013;88:104107. DOI: 10.1103/PhysRevB.88.104107

[80] Mei ZG, Stan M, Yang J. First-principles study of thermophysical properties of uranium dioxide. Journal of Alloys and Compounds. 2014;603:282-286. DOI: 10.1016/j. jallcom.2014.03.091

[81] Mei ZG, Stan M, Pichler B. First-principles study of structural, elastic, electronic, vibrational and thermodynamic properties of UN. Journal of Nuclear Materials. 2013;440:6369. DOI: 10.1016/j.jnucmat.2013.04.058

[82] Perdew JP, Burke K, Ernzerhof M. Generalized gradient approximation made simple. Physical Review Letters. 1996;77:3865-3868. DOI: 10.1103/PhysRevLett.77.3865

[83] Grimme S. Semiempirical GGA-type density functional constructed with a long-range dispersion correction. Journal of Computational Chemistry. 2006;27:1787-1799. DOI: 10.1002/jcc.20495

[84] Perdew JP, Ruzsinszky A, Csonka GI, Vydrov OA, Scuseria GE, Constantin LA, Zhou X, Burke K. Restoring the density-gradient expansion for exchange in solids and surfaces. Physical Review Letters. 2008;100:136406. DOI: 10.1103/PhysRevLett.100.136406

[85] Clark SJ, Segall MD, Pickard CJ, Hasnip PJ, Probert MIJ, Refson K, Payne MC. First principles methods using CASTEP. Zeitschrift für Kristallographie-Crystalline Materials. 2005;220:567-570. DOI: 10.1524/zkri.220.5.567.65075

[86] Materials Studio. Available from: http://accelrys.com/products/collaborativescience/bioviamaterials-studio/ [Accessed: 30-04-2018]

[87] Troullier N, Martins JL. Efficient pseudopotentials for plane-wave calculations. Physical Review B. 1991;43:1993-2006. DOI: 10.1103/PhysRevB.43.1993

[88] Pfrommer BG, Cote M, Louie MSG, Cohen ML. Relaxation of crystals with the QuasiNewton method. Journal of Computational Physics. 1997;131:233-240. DOI: 10.1006/jcph. 1996.5612

[89] Monkhorst HJ, Pack JD. Special points for Brillonin-zone integration. Physical Review B. 1976;13:5188-5192. DOI: 10.1103/PhysRevB.13.5188

[90] Yu R, Zhu RJ, Ye HQ. Calculations of single-crystal elastic constants made simple. Computer Physics Communications. 2010;181:671-675. DOI: 10.1016/j.cpc.2009.11.017 
[91] Birch F. Finite elastic strain of cubic crystal. Physical Review. 1947;71:809-824. DOI: 10.1103/PhysRev.71.809

[92] Angel RJ. Equations of state. Reviews in Mineralogy and Geochemistry. 2000;41:35-60. DOI: 10.2138/rmg.2000.41.2. EOSFIT 5.2 software, http://www.ccp14.ac.uk/ccp/webmirrors/ ross-angel/rja/soft/.10.2138/rmg.2000.41.2

[93] Colmenero F, Timon V. Study of the structural, vibrational and thermodynamic properties of natroxalate mineral using density functional theory. Journal of Solid State Chemistry. 2018;263:131-140. DOI: 10.1016/j.jssc.2018.04.022

[94] Colmenero F. Structural, spectroscopic and thermodynamic characterization of ammonium oxalate monohydrate mineral by means of theoretical solid-state methods. Journal of Physics and Chemistry of Solids. 2018. (accepted for publication)

[95] Milman V, Refson K, Clark SJ, Pickard CJ, Yates JR, Gao SP, Hasnip PJ, Probert MIJ, Perlov A, Segall MD. Electron and vibrational spectroscopies using DFT, plane waves and pseudopotentials: CASTEP implementation. Journal of Molecular Structure THEOCHEM. 2010;954:22-35. DOI: 10.1016/j.theochem.2009.12.040

[96] Hehre WJ, Radom L, Schleyer PVR, Pople JA. Ab Initio Molecular Orbital Theory. New York: Wiley; 1986. ISBN: 0471812412

[97] Finch RJ, Cooper MA, Hawthorne FC, Ewing RC. Refinement of the crystal structure of rutherfordine. The Canadian Mineralogist. 1999;37:929-938. ISSN: 0008-4476

[98] Ginderow D. Structure de l'Uranophane Alpha, $\mathrm{Ca}\left(\mathrm{UO}_{2}\right)_{2}\left(\mathrm{SiO}_{3} \mathrm{OH}\right)_{2} \cdot 5 \mathrm{H}_{2} \mathrm{O}$. Acta Crystallographica C. 1988;44:421-424. DOI: 10.1107/S0108270187011491

[99] Demartin F, Gramaccioli CM, Pilati T. The importance of accurate crystal structure determination of uranium minerals. II. Soddyite $\left(\mathrm{UO}_{2}\right)_{2}\left(\mathrm{SiO}_{4}\right) \cdot 2 \mathrm{H}_{2} \mathrm{O}$. Acta Crystallographica C. 1992;48:1-4. DOI: 10.1107/S0108270191004481

[100] Finch RJ, Cooper MA, Hawthorne FC, Ewing RC. The crystal structure of schoepite, $\left[\left(\mathrm{UO}_{2}\right)_{8}\right.$ $\left.\mathrm{O}_{2}(\mathrm{OH})_{12}\right] \cdot\left(\mathrm{H}_{2} \mathrm{O}\right)_{12}$. The Canadian Mineralogist. 1996;34:1071-1088. ISSN: 0008-4476

[101] Christ CL, Clark JR. Some observations on rutherfordine. American Mineralogist. 1956; 41:844-850. ISSN: 0003-004X

[102] Christ CL, Clark JR, Evans T. Crystal structure of rutherfordine, $\mathrm{UO}_{2} \mathrm{CO}_{3}$. Science. 1955;121:472-473. DOI: 10.1126/science.121.3144.472

[103] Stohl FV, Smith DK. The crystal chemistry of the uranyl silicate minerals. American Mineralogist. 1981;66:610-624. ISSN: 0003-004X

[104] Evans HT. Uranyl ion coordination. Science. 1963;141:154-158. DOI: 10.1126/science. 141.3576.154

[105] Weller MT, Light ME, Gelbrich T. Structure of uranium(VI) oxide dihydrate, $\mathrm{UO}_{3} \cdot 2 \mathrm{H}_{2} \mathrm{O}$; synthetic meta-schoepite $\left(\mathrm{UO}_{2}\right)_{4} \mathrm{O}(\mathrm{OH})_{6} \cdot 5 \mathrm{H}_{2} \mathrm{O}$. Acta Crystallographica B. 2000;56:577583. DOI: $10.1107 / \mathrm{S} 0108768199016559$ 
[106] Piret P. Structure cristalline de la fourmarierite, $\mathrm{Pb}\left[\left(\mathrm{UO}_{2}\right)_{4} \mathrm{O}_{3}(\mathrm{OH})_{4}\right] \cdot 4 \mathrm{H}_{2} \mathrm{O}$. Bulletin de la Société Française de Minéralogie et de Cristallographie. 1985;108:659-665. ISSN: 0037-9328

[107] Downs RT, Bartelmehs KL, Gibbs GV, Boisen MB. Interactive software for calculating and displaying $\mathrm{X}$-ray or neutron powder diffractometer patterns of crystalline materials. American Mineralogist. 1993;78:1104-1107. ISSN: 0003-004X

[108] Martin JD. XPowder12. Ver. 04.13, 2012. Available from: http://www.xpowder.com/ download/xpowder.pdf [Accessed: 30-04-2018]

[109] ICDD. The International Center for Diffraction Data. PDF-2 Database 2003. Available from: http://www.icdd.com/index.php/pdf-2/ [Accessed: 30-04-2018]

[110] Downs RT. The RRUFF Project: An Integrated Study of the Chemistry, Crystallography, Raman and Infrared Spectroscopy of Minerals. Program and Abstracts of the 19th General Meeting of the International Mineralogical Association in Kobe. Japan; 2006. O03-13. Available from: RRUFF Database web page, http://rruff.info/schoepite [Accessed: 30-04-2018]

[111] Born M. On the stability of crystal lattices. I. Mathematical Proceedings of the Cambridge Philosophical Society. 1940;36:160-172. DOI: 10.1017/S0305004100017138

[112] Born M, Huang K. Dynamics Theory of Crystal Lattices. Oxford: Oxford University Press; 1954. ISBN:0-19-850369-5

[113] Mouhat F, Coudert FX. Necessary and sufficient elastic stability conditions in various crystal systems. Physical Review B. 2014;90:224104. DOI: 10.1103/PhysRevB.90.224104

[114] Voigt W. Lehrbuch der Kristallphysik mit Ausschluss der Kristalloptik. Leipzig: Teubner; 1962. ISBN: 3663153169

[115] Reuss A. Berechnung der Fliessgrenze von Mischkristallen auf Grund der Plastizitatsbedingung fur Einkristalle. Journal of Applied Mathematics and Mechanics. 1929;9:49-58. DOI: 10.1002/zamm.19290090104

[116] Hill R. The elastic behaviour of a crystalline aggregate. Proceedings of the Physical Society of London. 1952;65:349-354. DOI: 10.1088/0370-1298/65/5/307

[117] Bouhadda Y, Djella S, Bououdina M, Fenineche N, Boudouma Y. Structural and elastic properties of $\mathrm{LiBH}_{4}$ for hydrogen storage applications. Journal of Alloys and Compounds. 2012;534:20-24. DOI: 10.1016/j.jallcom.2012.04.060

[118] Ulian G, Tosoni S, Valdre G. The compressional behaviour and the mechanical properties of talc $\left[\mathrm{Mg}_{3} \mathrm{Si}_{4} \mathrm{O}_{10}(\mathrm{OH})_{2}\right]$ : A density functional theory investigation. Physics and Chemistry of Minerals. 2014;41:639-650. DOI: 10.1007/s00269-014-0677-x

[119] Shang S, Wang $\mathrm{Y}$, Liu ZK. First-principles elastic constants of $\alpha$-and $\theta-\mathrm{Al}_{2} \mathrm{O}_{3}$. Applied Physics Letters. 2007;90:101909. DOI: 10.1063/1.2711762 
[120] Marmier A, Lethbridge ZAD, Walton RI, Smith CW, Parker SC, Evans KE. ElAM: A computer program for the analysis and representation of anisotropic elastic properties. Computer Physics Communications. 2010;181:2102-2115. DOI: 10.1016/j.cpc.2010.08.033

[121] Ravindran P, Fast L, Korzhavyi PA, Johansson B, Wills J, Eriksson O. Density functional theory for calculation of elastic properties of orthorhombic crystals: Application to $\mathrm{TiSi}_{2}$. Journal of Applied Physics. 1998;84:4891-4904. DOI: 10.1063/1.368733

[122] Pugh SF XCII. Relations between the elastic moduli and the plastic properties of polycrystalline pure metals. Philosophical Magazine. 1954;45:823-843. DOI: 10.1080/ 14786440808520496

[123] Niu H, Wei P, Sun Y, Chen CX, Franchini C, Li D, Li Y. Electronic, optical, and mechanical properties of superhard cold-compressed phases of carbon. Applied Physics Letters. 2011;99:031901. DOI: 10.1063/1.3610996

[124] Ranganathan SI, Ostoja-Starzewski M. Universal elastic anisotropy index. Physical Review Letters. 2008;101:055504. DOI: 10.1103/PhysRevLett.101.055504

[125] Wheaton V, Majumdar D, Balasubramanian K, Chauffe L, Allen PGA. Comparative theoretical study of uranyl silicate complexes. Chemical Physics Letters. 2003;371:349359. DOI: 10.1016/S0009-2614(03)00237-9

[126] Biwer DM, Ebert WL, Bates JK. The Raman spectra of several uranyl-containing minerals using a microprobe. Journal of Nuclear Materials. 1990;175:188-193. DOI: 10.1016/ 0022-3115(90)90205-2

[127] Schmidt AJ, Delegard CH. Assessment of K Basin Sludge Volume Expansion Resulting from Uranium Corrosion During Storage. Report of the U.S. Department of Energy, Pacific Northwest National laboratory PNNL-13786. Richland, Washington: US-DOE; 2002

[128] Delegard CH, Schmidt AJ, Chenault, JW. Mechanical Properties of K Basin Sludge Constituents and Their Surrogates. Report of the U.S. Department of Energy, Pacific Northwest National laboratory PNNL-14947. Richland, Washington: US-DOE; 2004 